\title{
Seed Priming with Potassium Nitrate and Gibberellic Acid Enhances the Performance of Dry Direct Seeded Rice (Oryza sativa L.) in North-Western India
}

\author{
Buta Singh Dhillon ${ }^{1, *}$, Virender Kumar ${ }^{2, *} \mathbb{0}$, Pardeep Sagwal ${ }^{3}$, Navjyot Kaur ${ }^{1}$, Gurjit Singh Mangat ${ }^{1}$ \\ and Sudhanshu Singh ${ }^{3}$ \\ 1 Department of Plant Breeding \& Genetics, Punjab Agricultural University, Ludhiana 141004, India; \\ navjyot_grewal@yahoo.com (N.K.); gsmangat-pbg@pau.edu (G.S.M.) \\ 2 International Rice Research Institute, Los Baños 4031, Philippines \\ 3 International Rice Research Institute, South Asia Regional Centre, Varanasi 221106, India; \\ p.sagwal@irri.org (P.S.); sud.singh@irri.org (S.S.) \\ * Correspondence: bsdhillon@pau.edu (B.S.D.); virender.kumar@irri.org (V.K.); Tel.: +91-8146100360 (B.S.D.); \\ +63-9175189431 (V.K.)
}

check for

updates

Citation: Dhillon, B.S.; Kumar, V.; Sagwal, P.; Kaur, N.; Singh Mangat, G.; Singh, S. Seed Priming with Potassium Nitrate and Gibberellic Acid Enhances the Performance of Dry Direct Seeded Rice (Oryza sativa L.) in North-Western India. Agronomy 2021, 11, 849. https://doi.org/ 10.3390/agronomy11050849

Academic Editor: Naeem Khan

Received: 5 March 2021

Accepted: 17 April 2021

Published: 27 April 2021

Publisher's Note: MDPI stays neutral with regard to jurisdictional claims in published maps and institutional affiliations.

Copyright: (c) 2021 by the authors. Licensee MDPI, Basel, Switzerland. This article is an open access article distributed under the terms and conditions of the Creative Commons Attribution (CC BY) license (https:/ / creativecommons.org/licenses/by/ $4.0 /)$.

\begin{abstract}
Poor early growth and uneven crop establishment are reported as the major bottlenecks in wide-scale adoption and optimal yield realization of dry direct-seeded rice (DSR). Seed priming can potentially help overcome these problems in DSR. Therefore, laboratory and field studies were conducted at Punjab Agricultural University, Ludhiana, India, during kharif / wet-season 2018 and 2019 to evaluate the effect of different priming techniques on germination, establishment, growth, and grain yield of rice under DSR conditions. The following priming treatments were evaluated: dry non-primed seed (control), hydropriming with distilled water, halopriming with $2.0 \%$ potassium nitrate, hormopriming with $50 \mathrm{ppm}$ gibberellic acid $\left(\mathrm{GA}_{3}\right)$, and osmopriming with polyethylene glycol (PEG) (-0.6 MPa), each with 12 and $24 \mathrm{~h}$ priming duration. In 2019, priming treatments were tested under two DSR establishment methods-conventional DSR (sowing in dry soil followed by irrigation) and soil mulch DSR (locally known as vattar DSR) (sowing in moist soil after pre-sowing irrigation), whereas in 2018, priming treatments were evaluated under conventional DSR only. In both years, halopriming and hormopriming resulted in a $7-11 \%$ increase in rice yields compared to non-primed dry seed (control). Osmopriming resulted in a $4 \%$ yield increase compared to control in 2018 but not in 2019. The higher yields in halopriming and hormopriming were attributed to higher and rapid germination/crop emergence, better root growth, and improvement in yield attributes. Priming effect on crop emergence, growth, and yield did not differ by DSR establishment methods and duration of priming. Conventional DSR and soil mulch DSR did not differ in grain yield, whereas they differed in crop emergence, growth, and yield attributes. These results suggest that halopriming with $2.0 \%$ potassium nitrate and hormopriming with 50 ppm $\mathrm{GA}_{3}$ has good potential to improve crop establishment and yield of rice in both conventional and soil mulch DSR systems.
\end{abstract}

Keywords: direct-seeded rice; gibberellic acid; PEG; potassium nitrate; productivity; root mass density; seed priming; vigor index

\section{Introduction}

Rice is a staple food for about $50 \%$ of the world population [1]. In India, rice is grown on 44.5 million hectares, accounting for $25 \%$ of global rice area and $21 \%$ of global rice production [2]. During 2019-2020, India exported 9.5 million MT of rice to countries such as Iran, Saudi Arab, Vietnam, USA, Nepal, Benin, Somalia, and Guinea etc. [3]. Therefore, the sustainability of Indian rice production is crucial for global food security. Additionally, in the future, to ensure both food security and environmental sustainability, it will be required to produce rice with a lower environmental footprint using less labor, water, and 
agrochemicals, while buffering the effect of climate change [4,5]. This requires paradigm shifts from the current resource-intensive rice cultivation method to resource-efficient and cost-effective cultivation methods [4,5].

In northwest India, where high yields of rice are quite common, rice is widely grown by the puddled transplanting (PTR) method during the kharif / wet-season (June to October/November) [4,6]. In this method, rice seedlings are first raised in a nursery. At about 25-30 days, seedlings are uprooted and manually transplanted to the puddled (wet-tilled) soil in the main field, and the field is then kept flooded for the majority of the season [4]. This method is preferred because of its several advantages, including assured good crop establishment, weed suppression [7], and higher nutrient availability under flooded/anaerobic conditions [8].

Recently, the sustainability of the flooded PTR method in northwest India has been threatened because it consumes a large amount of labor, water, and energy-all of which are becoming increasingly scarce and expensive in the region $[9,10]$. All of these factors present foundational challenges to sustaining high levels of rice production. The puddling operation in PTR also adversely affects the yield of the succeeding wheat crop in rotation by $8 \%$ due to its negative impact on soil physical properties [9]. Negative impact of puddling has also been reported on succeeding soybean crop [11]. Moreover, PTR is also associated with emissions of large amounts of greenhouse gas (GHG) in the form of methane, [12] and higher energy consumption [13]. All of these factors demand alternate methods that are labor-, water-, and energy-efficient, cost-effective, and mitigate climate change effects.

Dry direct-seeded rice (DSR) has emerged as a socio-economically viable and environmentally promising alternative to PTR to achieve productivity gains with lower water and labor utilization, production costs, and GHG emissions $[4,10,14,15]$. In DSR, seeds are directly sown (drill-sown with a machine or manually broadcast) in the main field, instead of nursery raising and transplanting rice seedlings as is the case in PTR. DSR can be established either by (1) sowing in dry soil followed by irrigation (conventional DSR) or by (2) sowing in moist soil after pre-sowing irrigation (locally known as vattar DSR, also known as soil mulch DSR $[12,16,17]$. Based on field studies conducted in the region, DSR in comparison to PTR provides multiple benefits, including savings in labor (by eliminating the processes of nursery raising, uprooting, and transplanting seedlings), water (18-50\%), cost of cultivation (INR 6436-7950 ha ${ }^{-1}$ ), and positively impacting succeeding wheat yield (8-10\%) in rotation, higher net income, and reduction in global warming potential $(32-44 \%)[9,10,13,18,19]$.

Risks of poor and non-uniform crop establishment and higher weed infestations are some of the constraints in the wide-scale adoption of DSR $[9,20,21]$. The rapid and uniform emergence with early vigor can lead to uniform and good crop establishment, which is crucial for attaining full yield potential and suppressing weeds in DSR [22,23]. In DSR, desired crop establishment is constrained by multiple factors, such as soil moisture drying associated with high temperatures, and inundation/flooding caused by monsoon rains during crop emergence/early establishment $[9,12,24]$. Soil mulch/vattar DSR, an innovative approach, was developed to address the issue of inundation risk because this method reduces the early irrigation requirement for the first 15 to 21 days by conserving soil moisture through the soil mulch effect $[25,26]$, and hence facilitates early planting of DSR (i.e., 2 to 3 weeks before the onset of the monsoon) which, in turn, reduces the risk of stand mortality caused by inundating rains during the early phases of crop growth. However, in this method, the top soil layer $(\sim 2 \mathrm{~cm})$ dries up very quickly; hence emergence can be affected by soil moisture depletion if seeds are not placed in the moist zone. In the conventional DSR method, there is a risk of temporary excess moisture stress, especially at places in the field where water stagnates at low-lying places in a non-leveled field or if rainfall occurs during the germination period leading to field inundation [4,9].

Sustainable and effective technologies are inevitable to improve the rapid and uniform crop emergence and early growth under DSR. Pre-sowing seed priming is one such technology [27] that suggests that the yield gap in DSR compared to PTR caused by poor crop 
establishment can be closed with seed priming technology. Improved seed invigoration techniques, such as seed priming for its positive impacts including rapid and uniform crop establishment, early vigor, and yield gains, have been studied in various crops including mungbean [28], soybean [29], sorghum [30], wheat [31,32], and maize [33,34], and vegetables such as tomato [35]. Recently, with increased interest in transitioning from PTR to DSR, limited studies have been conducted on rice seed priming [36,37].

Seed priming is defined as a pre-sowing treatment that partially hydrates seeds without allowing emergence [38]. Priming often involves soaking the seed in pre-determined amounts of water, called hydropriming. Control of the imbibition rate by osmotic agents such as polyethylene glycol (PEG) is referred to as osmopriming. Similarly, the use of specific salts for priming is called halopriming, and the use of plant growth regulators for priming is known as hormopriming [39]. In rice, although limited studies have been conducted on priming, these studies primarily demonstrated the positive impact on germination/emergence, rate of emergence, root growth, early seedling vigor, and early growth $[37,40,41]$, and a few studies also demonstrated the positive impact on grain yield and quality $[36,38]$. It has been reported that osmo-, hydro-, hormonal, and vitamin priming resulted in early and better crop establishment and early growth by enhancing amylase activity and total sugar in the seed [42]. Rice seed priming is, therefore, one of the most effective, pragmatic, and short-term approaches for increasing seed vigor and synchronization of germination under different stresses. Very limited information is available on the impact of seed priming on emergence and seedling growth and yield of DSR under Indian conditions where DSR is established using two methods-conventional and soil mulch DSR. To our knowledge, the impact of seed priming under vattar/soil mulch DSR has not been studied. Additionally, the majority of the previous seed priming studies were conducted under laboratory conditions with focus on germination/emergence and early growth, and very limited studies have evaluated the impact at grain yield [36,37]. Moreover, limited information is available on the impact of seed priming with $\mathrm{KNO}_{3}$ and $\mathrm{GA}_{3}$ on rice yield under DSR conditions. Therefore, research experiments were conducted with the objective to evaluate the effect of different types and durations of priming on germination, emergence, crop establishment, crop growth, and grain yield of rice under DSR conditions established by two methods.

\section{Materials and Methods}

\subsection{Experimental Site}

Experiments were conducted for two consecutive seasons (kharif / wet seasons (June to October/November) 2018 and 2019) at the Research Farm of Punjab Agricultural University, Ludhiana, India (30 $56^{\prime} \mathrm{N}$ latitude; $75^{\circ} 52^{\prime} \mathrm{E}$ longitude; $247 \mathrm{~m}$ altitude) located in the Western Indo-Gangetic Plains (WIGPs). The climate of the experimental site is characterized as subtropical, semi-arid with an annual rainfall of $733 \mathrm{~mm}$, of which about $80 \%$ is received during June to September [43]. The data on rainfall, sunshine hours, and maximum and minimum temperatures for the study period (2018 and 2019) were gathered at the agro-meteorological observatory of Punjab Agricultural University, Ludhiana, situated $200 \mathrm{~m}$ from the experimental site. Based on the initial soil analysis $(0-15 \mathrm{~cm}$ depth) conducted at the beginning of the study, the experimental site was Typical Ustipsamment (Fatehpur sandy-loam) in texture, low in available $\mathrm{N}\left(225 \mathrm{~kg} \mathrm{ha}^{-1}\right)$, and medium in available $\mathrm{P}\left(21.8 \mathrm{~kg} \mathrm{ha}^{-1}\right), \mathrm{K}\left(273 \mathrm{~kg} \mathrm{ha}^{-1}\right)$, and soil organic carbon $(0.42 \%)$. The soil $\mathrm{pH}(7.3)$ and electrical conductivity $\left(0.25 \mathrm{dSm}^{-1}\right.$ at $\left.25^{\circ} \mathrm{C}\right)$ were within the normal range.

\subsection{Experimental Details and Crop Management \\ 2.2.1. Laboratory Study}

Prior to the field experiment, a laboratory experiment was conducted in May 2018 to determine the effect of different priming treatments on the germination and vigor of rice seedlings. The experiment was conducted two times. Nine seed priming treatments were used, which were replicated four times in a randomized complete block design using the 
PR 126 variety of rice. The seed priming treatments undertaken were: dry seed (control), hydropriming, osmopriming with polyethylene glycol (PEG) (-0.6 MPa osmotic potential), halopriming with $2.0 \%$ potassium nitrate, and hormopriming with $50 \mathrm{ppm}$ gibberellic acid $\left(\mathrm{GA}_{3}\right)$. Seed priming was undertaken for two durations, i.e., 12 and $24 \mathrm{~h}$. Before initiating germination studies, the required number of paddy seeds was surface sterilized using $0.1 \%$ mercuric chloride for $2 \mathrm{~min}$, followed by thorough washing with distilled water to protect against any fungal infection. Seed germination was tested (one hundred seeds in each replication) using the "between paper" (BP) method in an incubator at $25^{\circ} \mathrm{C}$, keeping a day and night duration of $12 \mathrm{~h} \mathrm{[44].}$

\subsubsection{Field Study}

The same sets of nine treatments tested in the laboratory study were replicated thrice under field conditions during kharif 2018 in a randomized complete block design (RCBD). In 2018, seed priming treatments were evaluated under only the conventional DSR method (seeding in dry soil followed by irrigation). During kharif 2019, the seed priming treatments (factor 1) were evaluated under two DSR methods (factor 2): conventional DSR and vattar/soil mulch DSR in a factorial randomized complete block design. The solution of $50 \mathrm{ppm} \mathrm{GA}_{3}$ was prepared by dissolving $50 \mathrm{mg}$ of $\mathrm{GA}_{3}$ in ethyl alcohol $(2 \mathrm{~mL})$ followed by dilution to $1.0 \mathrm{~L}$ using distilled water. Potassium nitrate $\left(\mathrm{KNO}_{3}\right)$ solution of $2.0 \%$ was prepared by dissolving $20 \mathrm{~g}$ of $\mathrm{KNO}_{3}$ in $1.0 \mathrm{~L}$ distilled water. To prepare the solution with osmotic potential (OP) of $-0.6 \mathrm{MPa}, 21 \mathrm{~g}$ of PEG (polyethylene glycol) was dissolved in $1 \mathrm{~L}$ of water following the equation of Michaelis and Menten (1913) [45]. Hydropriming was performed by soaking one $\mathrm{kg}$ seed in one liter distilled water. Seed priming was performed for 12 and $24 \mathrm{~h}$ per treatment followed by drying of seed to its original moisture level before seeding. Short duration rice genotype PR 126 with 1000-grain weight $21.8 \mathrm{~g}$ was used and sown by conventional DSR and vattar/soil mulch DSR. For both methods, seeds were sown manually in rows. In the conventional DSR method, seeds were sown in well-prepared dry soil followed by irrigation immediately after sowing to facilitate crop emergence. For sowing, first rows/furrows were made using a hand plough, and then seeds were sown in furrows and covered with soil. In case of vattar/soil mulch DSR, pre-sowing irrigation was applied in a well-prepared soil followed by shallow tillage when the field reached the vattar (field capacity) condition and then rice sowing was conducted. Sowing was done using a hand-pulled plough where seeds were dropped at a depth of 1.5-2.0 cm through a funnel attached behind the plough while pulling it in a single operation. The layout and time of field operations in each year is presented as Supplementary Materials (Supplementary Figure S1 and Table S1).

In both methods, rice was sown at row spacing of $20 \mathrm{~cm}$ using a seed rate of $20 \mathrm{~kg} \mathrm{ha}^{-1}$ in plots measuring $10.8 \mathrm{~m}^{2}$. After sowing, the first post-sowing irrigation was applied 21 days after sowing (DAS) in vattar/soil mulch DSR, whereas in conventional DSR, postsowing irrigations were applied at $0,6,14$, and 21 DAS. Subsequent irrigations to both crops (conventional and vattar/soil mulch DSR) were scheduled and applied on similar days as per the crop demand. All other production and protection technologies were followed as per Punjab Agricultural University's recommendations [14]. The recommended dose of fertilizer (N, $150 \mathrm{~kg} \mathrm{ha}^{-1}$ and $\mathrm{ZnSO}_{4}(21 \%), 25 \mathrm{~kg} \mathrm{ha}^{-1}$ ) was applied to the crop. Nitrogen was applied through urea in three equal splits at 30, 45, and 63 days after sowing (DAS). Whole of the $\mathrm{ZnSO}_{4}$ was applied basal at the last field preparation. Due to sufficient $\mathrm{P}$ and $\mathrm{K}$ levels in the soil, these nutrients were not applied to the experiment crops.

\subsection{Data Collection}

\subsubsection{Laboratory Study}

Root and shoot lengths and seedling biomass were collected at termination of the experiment (14 DAS). Ten seedlings from each replication were measured using a centimeter scale and expressed in $\mathrm{cm}$ for measuring the root and shoot lengths. For dry matter accumulation (DMA), ten seedlings were dried in an oven at $65 \pm 2{ }^{\circ} \mathrm{C}$ until attainment of 
constant weight and were expressed in grams per 10 seedlings. Seedling vigor index I and

II were calculated by the formulae given below as described by [46]:

Seedling vigor index I $=$ Germination percentage $\times$ Total seedling length (Root + Shoot $)$ in $\mathrm{cm}$

Seedling vigor index II $=$ Germination percentage $\times$ Dry weight of ten seedlings in $g$

\subsubsection{Field Study}

Daily emergence counts until the plant population became constant were recorded from each plot, from two rows marked at $1 \mathrm{~m}$ on each side of the plot from the third row, to estimate days to first rice seedling emergence, synchrony of emergence (number of days for complete emergence), and total emergence, and time taken to $50 \%$ emergence $\left(\mathrm{T}_{50}\right) . \mathrm{T}_{50}$ was calculated using the following formula:

$$
\mathrm{T}_{50}=t_{i}+\frac{\left(\frac{N}{2}-n_{i}\right)\left(t_{j}-t_{i}\right)}{\left(n_{j}-n_{i}\right)}
$$

where $N$ is the number of final emerging seedlings, and $n_{j}$ and $n_{i}$ are the cumulative numbers of rice seedlings emerging by adjacent count at times $t_{j}$ and $t_{i}$, respectively, when $n_{i}<N / 2<n_{j}$.

The final plant population estimated at 25 DAS was expressed as number of plants per square meter. Plant height was recorded at crop maturity by randomly selecting five plants in each experimental unit, and it was measured from the ground level to the tip of panicle, excluding awns and expressed in centimeters. Days to $50 \%$ flowering were noted based on visual observations from each plot. The SPAD reading was noted at $50 \%$ flowering stage from 4 fully expanded apical leaf at $2 / 3$ position [47] from 10 rice plants in each plot, using a KONICA MINOLTA SPAD-502 PlusS/N:20001083 VER: 1.00.0501 Model. Root mass density was assessed at the anthesis stage (83 to 90 DAS depending on year and DSR method). For calculating root mass density, soil core samples were taken layer-wise (0-15 and $15-30 \mathrm{~cm}$ ) using a root sampling pipe with an internal diameter of $15 \mathrm{~cm}$. For this, five samples were taken continuously from $0.75 \mathrm{~m}$ row length per experimental unit. The soil samples thus obtained were washed in thin nylon mesh of one mm sieve in running water. The washed roots were picked up and then dried at $65{ }^{\circ} \mathrm{C}$ in an oven until reaching a constant weight. The root density was expressed as the weight of roots per unit volume of soil and calculated as follows:

$$
\text { Rooting density }\left(\mathrm{g} / \mathrm{cm}^{3}\right)=\frac{\text { Total root weight in particular depth }(\mathrm{g})}{\text { Total soil volume from which roots were collected }\left(\mathrm{cm}^{3}\right)}
$$

Total and effective tillers were counted from one meter row length from two locations at each plot and were expressed as tillers $\mathrm{m}^{-2}$ and panicles $\mathrm{m}^{-2}$. Five panicles were randomly selected from each experimental unit for recording panicle weight, and number of filled and unfilled grains per panicle. From the bulk samples, 1000 grains were counted and weighed on an electronic balance to obtain the 1000-seed weight. For estimating grain yield, a net area of $8.0 \mathrm{~m}^{2}(4.0 \mathrm{~m} \times 2.0 \mathrm{~m})$ was harvested from each plot and then threshed, sun dried, winnowed, cleaned, and weighed on an electronic balance. For valid comparison of different treatments, moisture in grains was estimated using a digital moisture meter (Kett's RICETER J Handheld grain moisture meter). Grain yield was adjusted at $14 \%$ moisture and expressed as $\mathrm{t} \mathrm{ha}^{-1}$. The weight of straw from each net plot was also recorded three days after harvest for estimation of straw yield, which was expressed as $\mathrm{tha}^{-1}$. 


\subsection{Statistical Analysis}

Data were subjected to 2-way analysis of variance (ANOVA) using the Proc GLM procedure of SAS software (SAS 9.3.) for laboratory study and 2018 field study using RCBD design and 3-ways analysis for 2019 field study using factorial RCBD design. For laboratory study, there was no treatment by run interaction; therefore, data of both runs were pooled and analyzed. For field study, data were analyzed year wise. The multiple comparisons among treatment means were carried out using Tukey's honest significance difference (HSD) test $(p \leq 0.05)$.

\section{Results}

\subsection{Weather Parameters}

Maximum air temperature varied from 31.3 to $37.6^{\circ} \mathrm{C}$ and 30.6 to $40.4{ }^{\circ} \mathrm{C}$, and minimum from 17.1 to $27.2^{\circ} \mathrm{C}$ and 18.4 to $26.8^{\circ} \mathrm{C}$ during kharif 2018 and 2019, respectively (Figure 1). The maximum temperature of study years was almost similar to the long-term average, whereas minimum temperature of study years was slightly higher, especially during 2019, than the long-term average. Total seasonal rainfall was similar in both years ( $843.0 \mathrm{~mm}$ in 2018 and $844.5 \mathrm{~mm}$ in 2019) but both years varied in rainfall distribution during the growing season. For example, there was more rainfall in June and July in 2018 than in 2019, whereas in August, it was higher in 2019 than in 2018. In September, the rainfall was almost similar in both years $(251 \mathrm{~mm}$ in 2018 and $265 \mathrm{~mm}$ in 2019). Similar to rainfall, total sunshine hours were also almost equal in both years (1015 and $1017 \mathrm{~h}$ in 2018 and 2019, respectively), but varied during the season, with higher sunshine hours in 2018 than in 2019 in the month of July, September, and October whereas it was the reverse in June and August. Overall, both seasons recorded above normal rainfall and below normal sunshine hours. The higher rainfall during September coincided with the grain filling period of the crop.

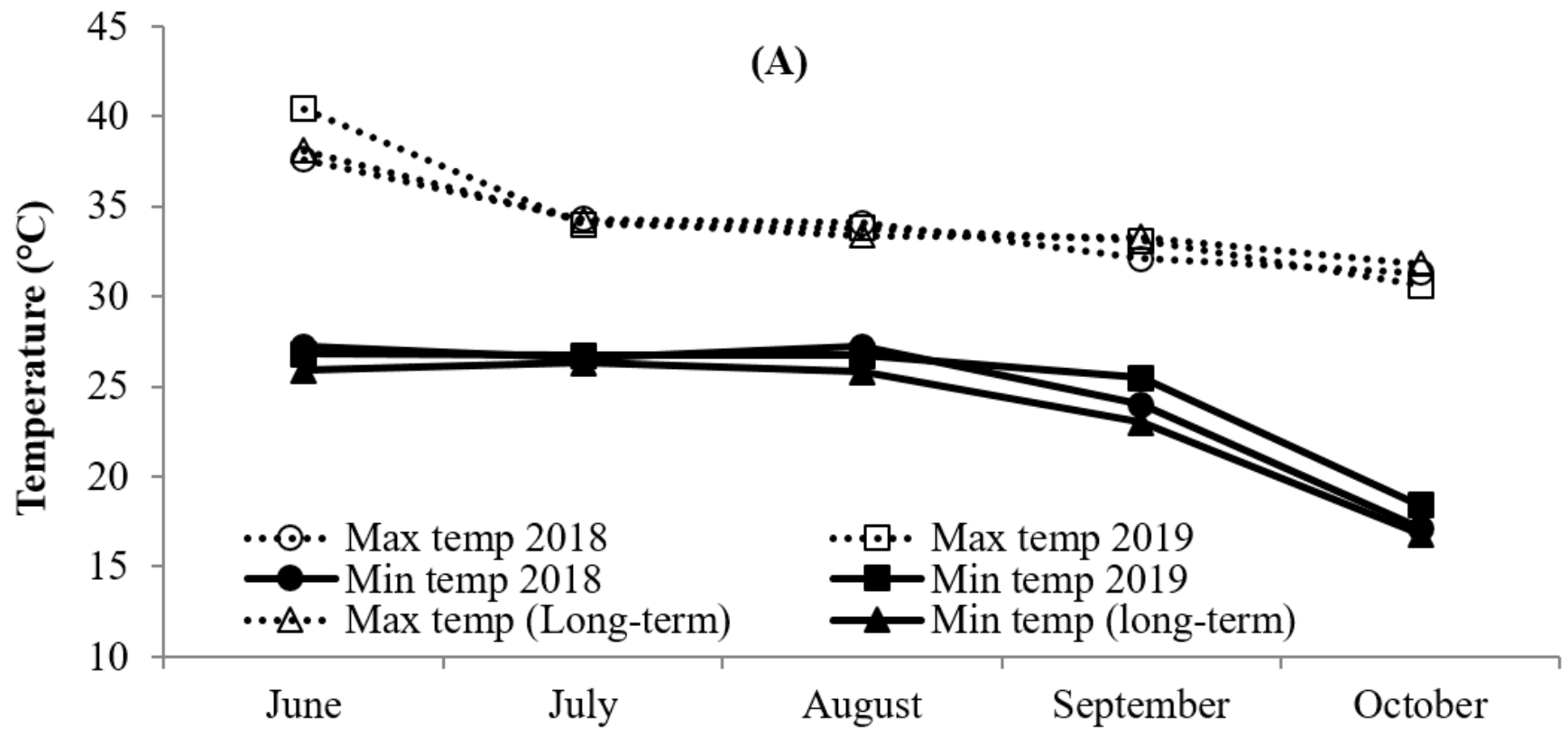

Figure 1. Cont. 

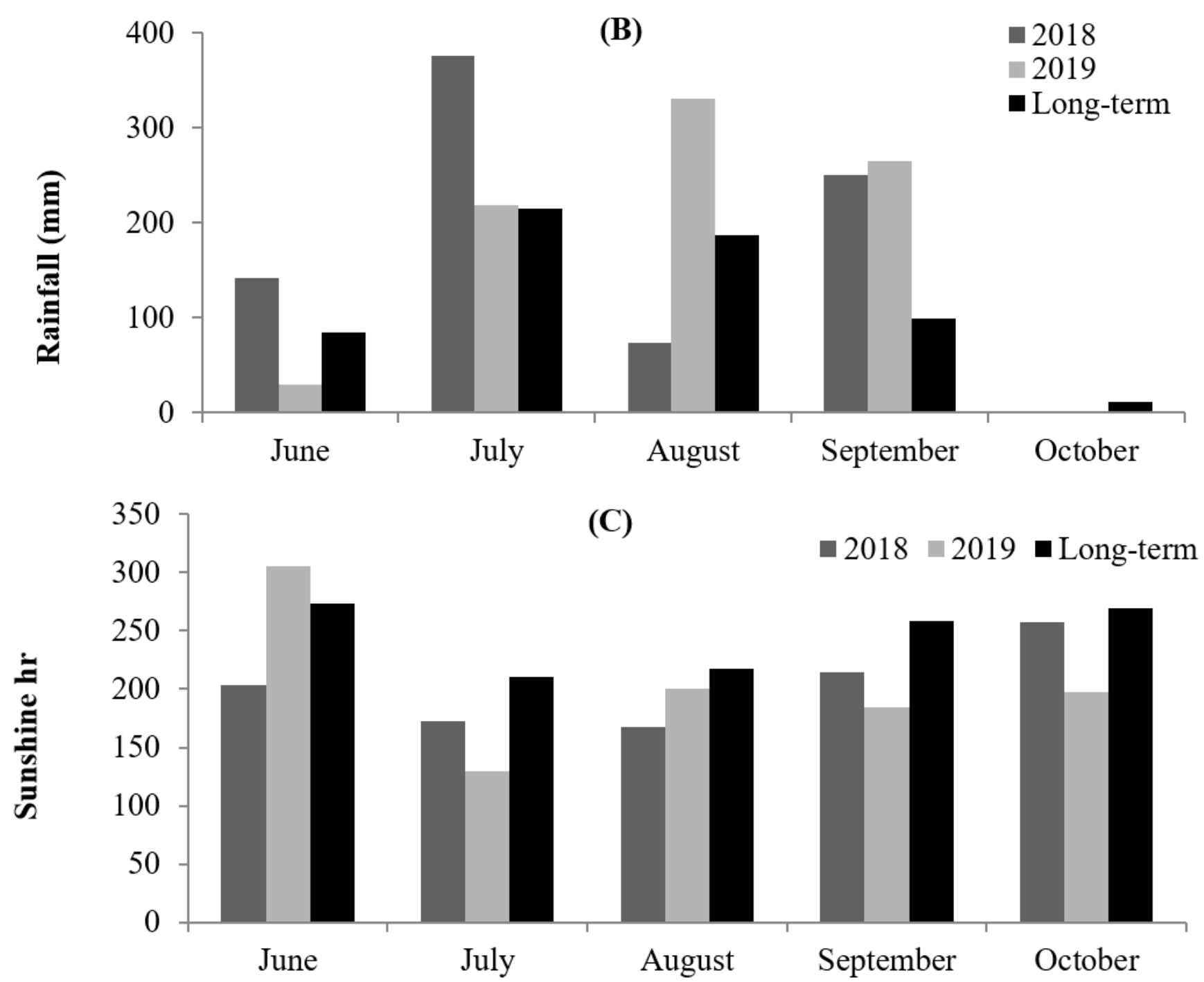

Figure 1. Mean monthly (A) temperature (minimum, maximum, and mean), (B) rainfall, and (C) sunshine hours during the study period (2018 and 2019 season) and of 10 year long-term average.

\subsection{Laboratory Study}

Results show that halopriming of seed with $2.0 \%$ potassium nitrate or hormopriming with 50 ppm $\mathrm{GA}_{3}$ enhanced seed germination by $3-4 \%$ compared to non-primed dry seed (control), whereas hydropriming and osmopriming with PEG did not affect seed germination (Table 1). Compared to the control (dry seed), all priming treatments except hydropriming had a positive impact on root growth with $20-27 \%$ increment in the root length. Only hormopriming with $\mathrm{GA}_{3}$ positively impacted shoot length with $21-22 \%$ higher shoot length compared to the control (dry seed). Hormopriming treatments had higher shoot length than the remaining treatments except halopriming treatments. Similar to root length, all priming treatments except hydropriming treatments improved the total seedling length. Priming treatments also significantly influenced vigor index 1 and vigor index 2. Osmopriming, halopriming, and hormopriming had a higher index vigor 1 than the control (dry seed) and hydropriming, whereas only halopriming and hormopriming had a higher vigor index 2 than the control, hydropriming, and osmopriming. There was improvement in root length, shoot length, and vigor indices, but it was not reflected in seedling dry matter accumulation within a short study period of 14 days. Duration of priming (12 or $24 \mathrm{~h}$ ) in all priming treatments (hydro-, osmo-, halo-, and hormopriming) was not significant for any of the growth parameters. 
Table 1. Effect of different seed priming techniques on germination, root and shoot length, dry weight (DW) accumulation, and vigor index of paddy seedlings (laboratory studies, average of two runs) ${ }^{1}$.

\begin{tabular}{lcccccc}
\hline Treatment & $\begin{array}{c}\text { Germination } \\
\mathbf{( \% )}\end{array}$ & $\begin{array}{c}\text { Root Length } \\
\mathbf{( c m )}\end{array}$ & $\begin{array}{c}\text { Shoot Length } \\
\mathbf{( c m})\end{array}$ & $\begin{array}{c}\text { DW of 10 } \\
\text { Seedlings }(\mathbf{g})\end{array}$ & Vigor Index 1 & Vigor Index 2 \\
\hline Control (dry seed) & $89 \pm 0.1 \mathrm{~b}$ & $12.8 \pm 0.2 \mathrm{c}$ & $12.1 \pm 0.3 \mathrm{~b}$ & $0.086 \pm 0.002 \mathrm{a}$ & $2219 \pm 10.7 \mathrm{e}$ & $7.7 \pm 0.04 \mathrm{~b}$ \\
Hydropriming 12 $\mathrm{h}$ & $89 \pm 0.7 \mathrm{~b}$ & $13.1 \pm 0.2 \mathrm{bc}$ & $12.4 \pm 0.1 \mathrm{~b}$ & $0.088 \pm 0.001 \mathrm{a}$ & $2267 \pm 6.3 \mathrm{e}$ & $7.8 \pm 0.03 \mathrm{~b}$ \\
Hydropriming 24 $\mathrm{h}$ & $89 \pm 0.6 \mathrm{~b}$ & $13.3 \pm 0.3 \mathrm{bc}$ & $12.6 \pm 0.2 \mathrm{~b}$ & $0.087 \pm 0.002 \mathrm{a}$ & $2302 \pm 28.3 \mathrm{de}$ & $7.7 \pm 0.03 \mathrm{~b}$ \\
Osmopriming12 $\mathrm{h}$ & $89 \pm 0.7 \mathrm{~b}$ & $16.3 \pm 0.3 \mathrm{a}$ & $12.6 \pm 0.4 \mathrm{~b}$ & $0.088 \pm 0.002 \mathrm{a}$ & $2560 \pm 25.7 \mathrm{c}$ & $7.8 \pm 0.01 \mathrm{~b}$ \\
Osmopriming 24 h & $88 \pm 0.6 \mathrm{~b}$ & $16.1 \pm 0.1 \mathrm{a}$ & $12.2 \pm 0.3 \mathrm{~b}$ & $0.088 \pm 0.002 \mathrm{a}$ & $2496 \pm 3.1 \mathrm{~cd}$ & $7.7 \pm 0.01 \mathrm{~b}$ \\
Halopriming 12 $\mathrm{h}$ & $92 \pm 0.3 \mathrm{a}$ & $15.0 \pm 0.3 \mathrm{ab}$ & $13.3 \pm 0.6 \mathrm{ab}$ & $0.091 \pm 0.002 \mathrm{a}$ & $2619 \pm 39.6 \mathrm{bc}$ & $8.4 \pm 0.03 \mathrm{a}$ \\
Halopriming 24 h & $92 \pm 0.6 \mathrm{a}$ & $15.7 \pm 0.8 \mathrm{a}$ & $13.4 \pm 0.6 \mathrm{ab}$ & $0.092 \pm 0.001 \mathrm{a}$ & $2676 \pm 92.3 \mathrm{abc}$ & $8.5 \pm 0.04 \mathrm{a}$ \\
Hormopriming 12 $\mathrm{h}$ & $93 \pm 0.6 \mathrm{a}$ & $15.3 \pm 0.8 \mathrm{ab}$ & $14.7 \pm 0.4 \mathrm{a}$ & $0.091 \pm 0.001 \mathrm{a}$ & $2790 \pm 95.6 \mathrm{ab}$ & $8.4 \pm 0.02 \mathrm{a}$ \\
Hormopriming 24 h & $93 \pm 0.6 \mathrm{a}$ & $15.9 \pm 0.3 \mathrm{a}$ & $14.8 \pm 0.4 \mathrm{a}$ & $0.091 \pm 0.003 \mathrm{a}$ & $2852 \pm 30.4 \mathrm{a}$ & $8.5 \pm 0.02 \mathrm{a}$ \\
\hline
\end{tabular}

${ }^{1}$ Within column, means followed by the same letter are not different at the 0.05 level of probability using Tukey's honest significance difference (HSD) test.

\subsection{Field Study \\ 3.3.1. Rate of Crop Emergence and Crop Establishment}

Both priming and DSR methods influenced time taken to $50 \%$ emergence $\left(\mathrm{T}_{50}\right)$, and days taken to start and completion of emergence. However, priming $\times$ DSR method interaction was non-significant for all of these parameters, suggesting that the effect of priming did not differ with DSR establishment methods (Tables 2 and 3). In both years, the rice emergence was faster in treatments with halopriming and hormopriming compared to the control (dry seeds without priming) as demonstrated by minimum value (days taken) for T50, and days taken to start and complete crop emergence. $\mathrm{T}_{50}$ was 1 day faster in halopriming and hormopriming compared to the control in 2018, and 2 days faster in 2019. Similarly, the time to start of emergence was 1 to 1.3 days earlier in 2018 and 1.5 to 2.0 days earlier in 2019 in halopriming and hormopriming than the control. The time to completion of rice emergence was 2 to 3 days earlier in both years in halopriming and hormopriming treatments compared to the control (dry seeds without priming). Other priming treatments did not differ from the control for these parameters.

Table 2. Time taken to 50\% emergence (T50), days taken to start and completion of emergence, and final plant population as affected by different seed priming in conventional direct-seeded rice (DSR) establishment method during 2018 at Ludhiana, India.

\begin{tabular}{lcccc}
\hline Treatment & $\begin{array}{c}\text { Time Taken to 50\% } \\
\text { Emergence (T50) }\end{array}$ & $\begin{array}{c}\text { Days Taken to Start of } \\
\text { Emergence }\end{array}$ & $\begin{array}{c}\text { Days Taken to } \\
\text { Completion of } \\
\text { Emergence }\end{array}$ & $\begin{array}{c}\text { Plant Population } \\
\text { (No. } \mathbf{~ m}^{-2} \text { ) }\end{array}$ \\
\hline Control (dry seed) & $10.3 \pm 0.2 \mathrm{a}$ & $6.3 \pm 0.3 \mathrm{a}$ & $13.0 \pm 0.6 \mathrm{a}$ & $85 \pm 0.1 \mathrm{a}$ \\
Hydropriming 12 $\mathrm{h}$ & $9.8 \pm 0.3 \mathrm{ab}$ & $5.7 \pm 0.2 \mathrm{ab}$ & $11.7 \pm 0.7 \mathrm{ab}$ & $88 \pm 0.7 \mathrm{a}$ \\
Hydropriming 24 $\mathrm{h}$ & $9.8 \pm 0.3 \mathrm{ab}$ & $5.7 \pm 0.3 \mathrm{ab}$ & $12.3 \pm 0.7 \mathrm{ab}$ & $87 \pm 0.6 \mathrm{a}$ \\
Osmopriming12 $\mathrm{h}$ & $9.9 \pm 0.4 \mathrm{ab}$ & $6.3 \pm 0.3 \mathrm{a}$ & $11.7 \pm 0.7 \mathrm{ab}$ & $88 \pm 0.7 \mathrm{a}$ \\
Osmopriming 24 h & $9.9 \pm 0.5 \mathrm{ab}$ & $6.3 \pm 0.3 \mathrm{a}$ & $11.0 \pm 0.6 \mathrm{ab}$ & $88 \pm 0.6 \mathrm{a}$ \\
Halopriming 12 $\mathrm{h}$ & $9.3 \pm 0.1 \mathrm{~b}$ & $5.3 \pm 0.3 \mathrm{~b}$ & $10.7 \pm 0.3 \mathrm{ab}$ & $87 \pm 0.3 \mathrm{a}$ \\
Halopriming 24 h & $9.3 \pm 0.1 \mathrm{~b}$ & $5.3 \pm 0.3 \mathrm{~b}$ & $10.3 \pm 0.3 \mathrm{~b}$ & $87 \pm 0.6 \mathrm{a}$ \\
Hormopriming 12 $\mathrm{h}$ & $9.2 \pm 0.1 \mathrm{~b}$ & $5.0 \pm 0.1 \mathrm{~b}$ & $10.0 \pm 0.1 \mathrm{~b}$ & $86 \pm 0.6 \mathrm{a}$ \\
Hormopriming 24 h & $9.2 \pm 0.1 \mathrm{~b}$ & $5.0 \pm 0.1 \mathrm{~b}$ & $10.0 \pm 0.1 \mathrm{~b}$ & $87 \pm 0.6 \mathrm{a}$ \\
\hline
\end{tabular}

Within column, means followed by the same letter are not different at the 0.05 level of probability using Tukey's HSD test.

In 2019, $\mathrm{T}_{50}$, and time to start and completion of rice emergence was 1 day faster in conventional DSR than in vattar/soil mulch DSR (Table 3). The final plant population did not differ by priming treatment in 2018 but was $6 \%$ to $8 \%$ higher in halopriming and hormopriming treatments compared to the control treatment. In both years, the final plant population in hydropriming and osmopriming was not different from the control treatment. 
Table 3. Time taken to 50\% emergence (T50), days taken to start and completion of emergence, and final plant population as affected by different seed priming and DSR establishment methods during 2019 at Ludhiana, India.

\begin{tabular}{|c|c|c|c|c|}
\hline Treatment & $\begin{array}{l}\text { Time Taken to } 50 \% \\
\text { Emergence (T50) }\end{array}$ & $\begin{array}{c}\text { Days Taken to Start } \\
\text { of Emergence }\end{array}$ & $\begin{array}{c}\text { Days Taken to Completion } \\
\text { of Emergence }\end{array}$ & $\begin{array}{l}\text { Plant Population } \\
\quad\left(\text { No. } \mathrm{m}^{-2}\right)\end{array}$ \\
\hline \multicolumn{5}{|c|}{ (A) Priming treatment } \\
\hline Control (dry seed) & $10.7 \pm 0.4 \mathrm{a}$ & $7.7 \pm 0.6 \mathrm{a}$ & $13.7 \pm 0.3 \mathrm{a}$ & $74.8 \pm 3.5 \mathrm{~d}$ \\
\hline Hydropriming $12 \mathrm{~h}$ & $9.9 \pm 0.3 \mathrm{abc}$ & $6.8 \pm 0.3 \mathrm{ab}$ & $12.7 \pm 0.3 \mathrm{abcd}$ & $76.8 \pm 3.5 \mathrm{bcd}$ \\
\hline Hydropriming $24 \mathrm{~h}$ & $9.8 \pm 0.4 \mathrm{bc}$ & $6.8 \pm 0.3 \mathrm{ab}$ & $12.8 \pm 0.4 \mathrm{abc}$ & $76.0 \pm 3.3 \mathrm{bcd}$ \\
\hline Osmopriming $12 \mathrm{~h}$ & $10.0 \pm 0.4 \mathrm{ab}$ & $7.0 \pm 0.4 \mathrm{ab}$ & $13.3 \pm 0.5 \mathrm{ab}$ & $75.3 \pm 3.6 \mathrm{~cd}$ \\
\hline Osmopriming $24 \mathrm{~h}$ & $9.9 \pm 0.5 \mathrm{abc}$ & $7.0 \pm 0.4 \mathrm{ab}$ & $13.3 \pm 0.5 \mathrm{ab}$ & $75.8 \pm 3.5 \mathrm{bcd}$ \\
\hline Halopriming $12 \mathrm{~h}$ & $9.2 \pm 0.5 \mathrm{~cd}$ & $6.2 \pm 0.3 b c$ & $11.5 \pm 0.5$ bcde & $79.3 \pm 3.2 \mathrm{ab}$ \\
\hline Halopriming $24 \mathrm{~h}$ & $8.7 \pm 0.3 \mathrm{~d}$ & $6.0 \pm 0.3 b c$ & $11.0 \pm 0.5$ cde & $79.0 \pm 3.3 \mathrm{abc}$ \\
\hline Hormopriming $12 \mathrm{~h}$ & $8.6 \pm 0.3 \mathrm{~d}$ & $5.7 \pm 0.2 c$ & $10.8 \pm 0.5 \mathrm{de}$ & $81.1 \pm 2.9 \mathrm{a}$ \\
\hline Hormopriming $24 \mathrm{~h}$ & $8.5 \pm 0.4 \mathrm{~d}$ & $\begin{array}{l}5.7 \pm 0.3 \mathrm{c} \\
\text { (B) DSR met }\end{array}$ & $10.7 \pm 0.4 \mathrm{e}$ & $81.0 \pm 2.8 \mathrm{a}$ \\
\hline Conventional DSR & $8.9 \pm 0.1 b$ & $6.0 \pm 0.1 \mathrm{~b}$ & $11.7 \pm 0.3 \mathrm{~b}$ & $85 \pm 0.5 a$ \\
\hline Soil mulch DSR & $10.1 \pm 0.2 \mathrm{a}$ & $7.1 \pm 0.2 \mathrm{a}$ & $12.7 \pm 0.3 \mathrm{a}$ & $71 \pm 0.6 b$ \\
\hline \multicolumn{5}{|c|}{ ANOVA ( $p$-value) } \\
\hline Priming $(\mathrm{P})$ & $<0.0001$ & $<0.0001$ & $<0.0001$ & $<0.0001$ \\
\hline DSR method (M) & $<0.0001$ & $<0.0001$ & 0.002 & $<0.0001$ \\
\hline $\mathrm{P} \times \mathrm{M}$ interaction & NS & NS & NS & NS \\
\hline
\end{tabular}

Within column for each factor, means followed by the same small letter are not different at the 0.05 level of probability using Tukey's HSD test.

\subsubsection{Crop Growth and SPAD Value}

In both years, seed priming treatments did not influence rice plant height and days to $50 \%$ flowering but both parameters were significantly influenced by the DSR methods (Tables 4 and 5). The plant height was $2 \mathrm{~cm}$ higher in vattar/soil mulch DSR than in the conventional DSR method. In addition, days to $50 \%$ flowering under vattar DSR was delayed by 4 days compared to the conventional DSR method.

Table 4. Plant height, tiller number, days to flower and SPAD value as affected by different seed priming in conventional DSR establishment method during 2018 at Ludhiana, India.

\begin{tabular}{lcccc}
\hline Treatment & Plant Height $\mathbf{( c m )}$ & Tillers (Number $\mathbf{~ m}^{-2}$ ) & Days to Flowering (Days) & SPAD Value \\
\hline Control (dry seed) & $95 \pm 3.1 \mathrm{a}$ & $512 \pm 1.2 \mathrm{c}$ & $82 \pm 0.3 \mathrm{a}$ & $35.4 \pm 0.2 \mathrm{~b}$ \\
Hydropriming 12 $\mathrm{h}$ & $96 \pm 0.5 \mathrm{a}$ & $512 \pm 2.3 \mathrm{c}$ & $81 \pm 1.0 \mathrm{a}$ & $35.6 \pm 0.3 \mathrm{~b}$ \\
Hydropriming 24 $\mathrm{h}$ & $96 \pm 1.1 \mathrm{a}$ & $511 \pm 2.6 \mathrm{c}$ & $81 \pm 0.6 \mathrm{a}$ & $35.6 \pm 0.3 \mathrm{~b}$ \\
Osmopriming12 $\mathrm{h}$ & $98 \pm 0.4 \mathrm{a}$ & $517 \pm 5.5 \mathrm{bc}$ & $82 \pm 0.3 \mathrm{a}$ & $37.7 \pm 0.3 \mathrm{a}$ \\
Osmopriming 24 $\mathrm{h}$ & $98 \pm 0.8 \mathrm{a}$ & $517 \pm 3.3 \mathrm{bc}$ & $82 \pm 0.3 \mathrm{a}$ & $37.5 \pm 0.3 \mathrm{a}$ \\
Halopriming 12 $\mathrm{h}$ & $99 \pm 2.0 \mathrm{a}$ & $540 \pm 3.1 \mathrm{ab}$ & $80 \pm 0.9 \mathrm{a}$ & $37.4 \pm 0.2 \mathrm{a}$ \\
Halopriming 24 h & $100 \pm 1.7 \mathrm{a}$ & $550 \pm 8.1 \mathrm{a}$ & $80 \pm 0.3 \mathrm{a}$ & $37.5 \pm 0.6 \mathrm{a}$ \\
Hormopriming 12 $\mathrm{h}$ & $99 \pm 1.6 \mathrm{a}$ & $539 \pm 3.3 \mathrm{ab}$ & $80 \pm 1.2 \mathrm{a}$ & $37.4 \pm 0.1 \mathrm{a}$ \\
Hormopriming 24 h & $100 \pm 1.3 \mathrm{a}$ & $541 \pm 7.4 \mathrm{ab}$ & $37.4 \pm 0.8 \mathrm{a}$ \\
\hline
\end{tabular}

Within column, means followed by the same letter are not different at the 0.05 level of probability using Tukey's HSD test.

Both priming techniques and DSR methods influenced tiller density and SPAD value, but the effect of priming did not differ with DSR establishment method, as demonstrated by non-significant priming $\times$ DSR method interaction (Table 5 ). In both years, the tiller density in osmopriming and hydropriming treatments was similar to the control (dry and non-primed seed). Tiller density in halopriming and hormopriming treatments was $5-7 \%$ higher than control and hydropriming treatments in 2018, whereas in 2019, tiller density was $8-11 \%$ higher in halopriming and hormopriming treatments compared to osmopriming, hydropriming, and control treatments.

In both years, the SPAD value in all priming treatments except hydropriming was higher than the control. In 2018, SPAD values in control and hydropriming ranged from 35.4 to 35.6 , whereas in other priming treatments, they ranged from 37.4 to 37.7. In 2019, 
they ranged from 34.7 to 34.8 in the control and hydropriming, and from 36.3 to 36.8 in the other priming treatments. In 2019, among DSR methods (Table 5), the SPAD value was higher in vattar/soil mulch DSR (37.1) than conventional DSR (34.8).

Table 5. Plant height, tiller number, days to flower and SPAD value as affected by different seed priming and DSR establishment methods during 2019 at Ludhiana, India.

\begin{tabular}{|c|c|c|c|c|}
\hline Treatment & Plant Height (cm) & Tillers (Number $\mathrm{m}^{-2}$ ) & Days to Flowering (Days) & SPAD Value \\
\hline \multicolumn{5}{|c|}{ (A) Priming treatment } \\
\hline Control (dry seed) & $98 \pm 1.1 \mathrm{a}$ & $421 \pm 6.4 \mathrm{~b}$ & $83 \pm 0.8 \mathrm{a}$ & $34.7 \pm 0.7 \mathrm{~b}$ \\
\hline Hydropriming $12 \mathrm{~h}$ & $98 \pm 1.1 \mathrm{a}$ & $425 \pm 6.6 b$ & $82 \pm 0.8 \mathrm{a}$ & $34.7 \pm 0.6 \mathrm{~b}$ \\
\hline Hydropriming $24 \mathrm{~h}$ & $97 \pm 0.9 \mathrm{a}$ & $425 \pm 7.2 \mathrm{~b}$ & $82 \pm 0.8 \mathrm{a}$ & $34.8 \pm 0.7 \mathrm{~b}$ \\
\hline Osmopriming $12 \mathrm{~h}$ & $98 \pm 0.8 \mathrm{a}$ & $429 \pm 7.3 b$ & $82 \pm 0.8 \mathrm{a}$ & $36.4 \pm 0.6 \mathrm{a}$ \\
\hline Osmopriming $24 \mathrm{~h}$ & $98 \pm 0.9 \mathrm{a}$ & $426 \pm 5.8 b$ & $83 \pm 0.8 \mathrm{a}$ & $36.3 \pm 0.6 \mathrm{a}$ \\
\hline Halopriming $12 \mathrm{~h}$ & $99 \pm 0.6 \mathrm{a}$ & $463 \pm 4.8 \mathrm{a}$ & $82 \pm 0.8 \mathrm{a}$ & $36.5 \pm 0.6 \mathrm{a}$ \\
\hline Halopriming $24 \mathrm{~h}$ & $99 \pm 1.0 \mathrm{a}$ & $463 \pm 3.4 \mathrm{a}$ & $81 \pm 0.8 \mathrm{a}$ & $36.6 \pm 0.5 \mathrm{a}$ \\
\hline Hormopriming $12 \mathrm{~h}$ & $101 \pm 1.3 \mathrm{a}$ & $462 \pm 5.6 \mathrm{a}$ & $81 \pm 0.8 \mathrm{a}$ & $36.8 \pm 0.5 \mathrm{a}$ \\
\hline Hormopriming $24 \mathrm{~h}$ & $101 \pm 1.3 \mathrm{a}$ & $\begin{array}{l}469 \pm 5.1 \text { a } \\
\text { (B) DSR method }\end{array}$ & $81 \pm 0.9 \mathrm{a}$ & $36.7 \pm 0.5 \mathrm{a}$ \\
\hline Conventional DSR & $98 \pm 0.5 \mathrm{~b}$ & $452 \pm 3.3 \mathrm{a}$ & $80 \pm 0.2 b$ & $34.8 \pm 0.2 \mathrm{~b}$ \\
\hline Soil mulch DSR & $100 \pm 0.5 \mathrm{a}$ & $433 \pm 5.0 \mathrm{~b}$ & $84 \pm 0.2 \mathrm{a}$ & $37.1 \pm 0.2 \mathrm{a}$ \\
\hline \multicolumn{5}{|c|}{ ANOVA ( $p$-value) } \\
\hline Priming $(\mathrm{P})$ & NS & $<0.0001$ & NS & $<0.0001$ \\
\hline DSR method (M) & $<0.0001$ & $<0.0001$ & $<0.0001$ & $<0.0001$ \\
\hline $\mathrm{P} \times \mathrm{M}$ interaction & NS & NS & NS & NS \\
\hline
\end{tabular}

Within column for each factor, means followed by the same small letter are not different at the 0.05 level of probability using Tukey's HSD test.

\subsubsection{Root Mass Density}

Priming techniques and DSR methods influenced root mass density at both depths $(0-15 \mathrm{~cm}$ and 15-30 cm) but the interaction between priming and DSR method was nonsignificant (Tables 6 and 7). In 2018, the root mass density of conventional DSR at 0-15 cm depth was highest in osmopriming for $24 \mathrm{~h}\left(4.85 \mathrm{mg} \mathrm{cc}^{-1}\right)$ which was at par with halopriming and hormopriming for $24 \mathrm{~h}$, but was higher than halopriming and hormopriming for $12 \mathrm{~h}$ treatments. The lowest root mass density was in control and hydropriming treatments (3.39 to $3.45 \mathrm{mgcc}^{-1}$ ) and was lower than all other priming treatments. At $15-30 \mathrm{~cm}$ depth, root mass density in osmopriming, halopriming, and hormopriming treatments was higher (ranging from 0.410 to $0.428 \mathrm{mgcc}^{-1}$ ) than control and hydropriming treatments (ranging from 0.324 to $0.334 \mathrm{mg} \mathrm{cc}^{-1}$ ). In 2019 , a similar trend was observed in root mass density at both depths to that observed in 2018. In 2019, root mass density was higher in vattar/soil mulch DSR than conventional DSR at both depths (Table 7) (4.6 versus $3.8 \mathrm{mg} \mathrm{cc}^{-1}$ at $0-15 \mathrm{~cm}$ and 0.40 versus $0.37 \mathrm{mg} \mathrm{cc}^{-1}$ at $15-30 \mathrm{~cm}$ depth).

Table 6. Root mass density of rice under different seed priming techniques in conventional DSR establishment method during 2018 at Ludhiana, India.

\begin{tabular}{lcc}
\hline \multirow{2}{*}{ Treatment } & \multicolumn{2}{c}{ Root Mass Density $(\mathbf{m g} / \mathbf{c c})$ in Different Layers } \\
\cline { 2 - 3 } & $\mathbf{0 - 1 5} \mathbf{~ c m}$ & $\mathbf{1 5 - 3 0 ~} \mathbf{~ c m}$ \\
\hline Control (dry seed) & $3.39 \pm 0.04 \mathrm{c}$ & $0.324 \pm 0.01 \mathrm{~b}$ \\
Hydropriming 12 h & $3.39 \pm 0.02 \mathrm{c}$ & $0.334 \pm 0.02 \mathrm{~b}$ \\
Hydropriming 24 h & $3.45 \pm 0.06 \mathrm{c}$ & $0.327 \pm 0.03 \mathrm{~b}$ \\
Osmopriming12 $\mathrm{h}$ & $4.66 \pm 0.02 \mathrm{ab}$ & $0.428 \pm 0.01 \mathrm{a}$ \\
Osmopriming 24 h & $4.85 \pm 0.02 \mathrm{a}$ & $0.424 \pm 0.01 \mathrm{a}$ \\
Halopriming 12 $\mathrm{h}$ & $4.27 \pm 0.13 \mathrm{~b}$ & $0.410 \pm 0.01 \mathrm{a}$ \\
Halopriming 24 h & $4.42 \pm 0.04 \mathrm{ab}$ & $0.416 \pm 0.01 \mathrm{a}$ \\
Hormopriming 12 h & $4.31 \pm 0.01 \mathrm{~b}$ & $0.414 \pm 0.01 \mathrm{a}$ \\
Hormopriming 24 h & $4.51 \pm 0.24 \mathrm{ab}$ & $0.420 \pm 0.02 \mathrm{a}$ \\
\hline
\end{tabular}

Within column, means followed by the same letter are not different at the 0.05 level of probability using Tukey's HSD test. 
Table 7. Root mass density of rice under different seed priming techniques and DSR establishment methods during 2019 at Ludhiana, India.

\begin{tabular}{|c|c|c|}
\hline \multirow{2}{*}{ Treatment } & \multicolumn{2}{|c|}{ Root Mass Density (mg/cc) in Different Layers } \\
\hline & $0-15 \mathrm{~cm}$ & $15-30 \mathrm{~cm}$ \\
\hline & (A) Priming treatment & \\
\hline Control (dry seed) & $3.47 \pm 0.22 \mathrm{~d}$ & $0.33 \pm 0.01 b$ \\
\hline Hydropriming $12 \mathrm{~h}$ & $3.47 \pm 0.21 \mathrm{~d}$ & $0.33 \pm 0.01 b$ \\
\hline Hydropriming $24 \mathrm{~h}$ & $3.49 \pm 0.25 \mathrm{~d}$ & $0.33 \pm 0.01 \mathrm{~b}$ \\
\hline Osmopriming $12 \mathrm{~h}$ & $4.66 \pm 0.16 \mathrm{ab}$ & $0.42 \pm 0.01 \mathrm{a}$ \\
\hline Osmopriming $24 \mathrm{~h}$ & $4.70 \pm 0.16 \mathrm{a}$ & $0.42 \pm 0.01 \mathrm{a}$ \\
\hline Halopriming $12 \mathrm{~h}$ & $4.44 \pm 0.16 \mathrm{bc}$ & $0.40 \pm 0.01 \mathrm{a}$ \\
\hline Halopriming $24 \mathrm{~h}$ & $4.54 \pm 0.15 \mathrm{abc}$ & $0.40 \pm 0.01 \mathrm{a}$ \\
\hline Hormopriming $12 \mathrm{~h}$ & $4.42 \pm 0.17 \mathrm{c}$ & $0.40 \pm 0.01 \mathrm{a}$ \\
\hline \multirow[t]{2}{*}{ Hormopriming $24 \mathrm{~h}$} & $4.47 \pm 0.17 \mathrm{bc}$ & $0.40 \pm 0.01 \mathrm{a}$ \\
\hline & (B) DSR method & \\
\hline Conventional DSR & $3.79 \pm 0.1 b$ & $0.37 \pm 0.01 b$ \\
\hline Soil mulch DSR & $4.59 \pm 0.1 \mathrm{a}$ & $0.40 \pm 0.01 \mathrm{a}$ \\
\hline \multicolumn{3}{|c|}{ ANOVA ( $p$-value) } \\
\hline Priming $(\mathrm{P})$ & $<0.0001$ & $<0.0001$ \\
\hline DSR method (M) & $<0.0001$ & $<0.0001$ \\
\hline $\mathrm{P} \times \mathrm{M}$ interaction & NS & NS \\
\hline
\end{tabular}

Within column for each factor, means followed by the same small letter are not different at the 0.05 level of probability using Tukey's HSD test.

\subsubsection{Yield and Yield Attributes}

In both years, hydropriming and osmopriming did not differ from control in panicle numbers (Tables 8 and 9). In contrast, halopriming and hormopriming did not differ between themselves but had 7-11\% higher panicle numbers than control, hydropriming, and osmopriming treatments in both years. Overall, panicle numbers were higher in 2018 than in 2019 ( 505 versus $418 \mathrm{~m}^{-2}$ ), and also in the conventional DSR method than in vattar/soil mulch DSR in 2019 (431 versus $404 \mathrm{~m}^{-2}$ ).

Table 8. Yield attributes (panicle no., panicle weight, and 1000-grain weight) of rice as affected by different seed priming in conventional DSR establishment method during 2018 at Ludhiana, India.

\begin{tabular}{cccc}
\hline Treatment & Panicles (No. $\mathbf{~ m}^{-\mathbf{2}}$ ) & Panicle Weight (g) & 1000-Grain Weight (g) \\
\hline Control (dry seed) & $480 \pm 4.6 \mathrm{~b}$ & $3.08 \pm 0.11 \mathrm{a}$ & $21.7 \mathrm{a} \pm 0.2$ \\
Hydropriming 12 $\mathrm{h}$ & $485 \pm 2.7 \mathrm{~b}$ & $3.08 \pm 0.08 \mathrm{a}$ & $21.7 \mathrm{a} \pm 0.2$ \\
Hydropriming 24 $\mathrm{h}$ & $481 \pm 0.7 \mathrm{~b}$ & $3.11 \pm 0.06 \mathrm{a}$ & $21.7 \mathrm{a} \pm 0.03$ \\
Osmopriming 12 $\mathrm{h}$ & $489 \pm 5.8 \mathrm{~b}$ & $3.15 \pm 0.01 \mathrm{a}$ & $21.7 \mathrm{a} \pm 0.2$ \\
Osmopriming 24 h & $487 \pm 3.7 \mathrm{~b}$ & $3.16 \pm 0.01 \mathrm{a}$ & $21.7 \mathrm{a} \pm 0.2$ \\
Halopriming 12 $\mathrm{h}$ & $523 \pm 2.7 \mathrm{a}$ & $3.13 \pm 0.04 \mathrm{a}$ & $21.7 \mathrm{a} \pm 0.7$ \\
Halopriming 24 h & $524 \pm 4.7 \mathrm{a}$ & $3.11 \pm 0.02 \mathrm{a}$ & $21.7 \mathrm{a} \pm 0.9$ \\
Hormopriming 12 $\mathrm{h}$ & $523 \pm 5.3 \mathrm{a}$ & $3.11 \pm 0.11 \mathrm{a}$ & $21.6 \mathrm{a} \pm 0.6$ \\
Hormopriming 24 h & $525 \pm 4.7 \mathrm{a}$ & $3.11 \pm 0.07 \mathrm{a}$ & $21.7 \mathrm{a} \pm 0.3$ \\
\hline
\end{tabular}

Within column, means followed by the same letter are not different at the 0.05 level of probability using Tukey's HSD test.

The panicle weight and 1000-grain weight were not affected by priming treatments in both years (Tables 8 and 9). In 2019, (Table 9), 1000-grain weight was also not affected by DSR methods but panicle weight was influenced by DSR methods with $17 \%$ higher panicle weight in vattar/soil mulch DSR than conventional DSR ( 3.30 versus $2.83 \mathrm{~g} \cdot$ panicle $^{-1}$ ).

Filled grains per panicle only in 2019, and unfilled grains and sterility in both years, were significantly affected by priming treatments (Tables 10 and 11). These parameters were also significantly influenced by DSR methods; however, the interaction effect (priming $\times$ DSR method) was non-significant (Table 10). In 2019, filled grains per panicle in osmopriming, halopriming, and hormopriming treatments were $3 \%$ to $6 \%$ higher than in control and 
hydropriming treatments. Filled grains per panicle were also higher (22 grains panicle ${ }^{-1}$ or $18 \%$ ) in vattar/soil mulch DSR than in the conventional DSR method (Table 11).

Table 9. Yield attributes (panicle no., panicle weight, and 1000-grain weight) of rice as affected by different seed priming and DSR establishment methods during 2019 at Ludhiana, India.

\begin{tabular}{|c|c|c|c|}
\hline Treatment & Panicles (No. $\mathrm{m}^{-2}$ ) & Panicle Weight (g) & 1000-Grain Weight (g) \\
\hline \multicolumn{4}{|c|}{ (A) Priming treatment } \\
\hline Control (dry seed) & $400 \pm 9.1 \mathrm{~b}$ & $3.00 \pm 0.12 \mathrm{a}$ & $21.4 \pm 0.1 \mathrm{a}$ \\
\hline Hydropriming $12 \mathrm{~h}$ & $399 \pm 7.1 b$ & $3.00 \pm 0.12 \mathrm{a}$ & $21.4 \pm 0.3 \mathrm{a}$ \\
\hline Hydropriming $24 \mathrm{~h}$ & $404 \pm 7.1 \mathrm{~b}$ & $2.99 \pm 0.13 \mathrm{a}$ & $21.4 \pm 0.2 \mathrm{a}$ \\
\hline Osmopriming $12 \mathrm{~h}$ & $402 \pm 5.0 \mathrm{~b}$ & $3.16 \pm 0.11 \mathrm{a}$ & $21.6 \pm 0.2 \mathrm{a}$ \\
\hline Osmopriming $24 \mathrm{~h}$ & $401 \pm 9.9 \mathrm{~b}$ & $3.17 \pm 0.1 \mathrm{a}$ & $21.5 \pm 0.3 \mathrm{a}$ \\
\hline Halopriming $12 \mathrm{~h}$ & $438 \pm 5.2 \mathrm{a}$ & $3.06 \pm 0.15 a$ & $21.5 \pm 0.3 \mathrm{a}$ \\
\hline Halopriming $24 \mathrm{~h}$ & $436 \pm 7.1 \mathrm{a}$ & $3.07 \pm 0.15 \mathrm{a}$ & $21.5 \pm 0.2 \mathrm{a}$ \\
\hline Hormopriming $12 \mathrm{~h}$ & $439 \pm 7.2 \mathrm{a}$ & $3.08 \pm 0.12 \mathrm{a}$ & $21.4 \pm 0.3 \mathrm{a}$ \\
\hline Hormopriming $24 \mathrm{~h}$ & $441 \pm 6.1 \mathrm{a}$ & $3.07 \pm 0.13 \mathrm{a}$ & $21.5 \pm 0.4 \mathrm{a}$ \\
\hline \multicolumn{4}{|c|}{ (B) DSR method } \\
\hline Conventional DSR & $431 \pm 3.5 \mathrm{a}$ & $2.83 \pm 0.02 b$ & $21.3 \pm 0.1$ \\
\hline Soil mulch DSR & $404 \pm 4.6 \mathrm{~b}$ & $3.30 \pm 0.04 \mathrm{a}$ & $21.6 \pm 0.1$ \\
\hline \multicolumn{4}{|c|}{ ANOVA ( $p$-value) } \\
\hline Priming $(\mathrm{P})$ & $<0.0001$ & NS & NS \\
\hline DSR method (M) & $<0.0001$ & $<0.0001$ & NS \\
\hline $\mathrm{P} \times \mathrm{M}$ interaction & NS & NS & NS \\
\hline
\end{tabular}

Table 10. Yield attributes (filled and unfilled grains per panicle and sterility \%) of rice as affected by different seed priming in conventional DSR establishment method during 2018 at Ludhiana, India.

\begin{tabular}{lccc}
\hline Treatment & $\begin{array}{c}\text { Number of Filled } \\
\text { Grain Per Panicle }\end{array}$ & $\begin{array}{c}\text { Number of Unfilled } \\
\text { Grain Per Panicle }\end{array}$ & Sterility (\%) \\
\hline Control (dry seed) & $140 \pm 3.7 \mathrm{a}$ & $25 \pm 1.0 \mathrm{a}$ & $15 \pm 0.7 \mathrm{a}$ \\
Hydropriming 12 $\mathrm{h}$ & $141 \pm 4.5 \mathrm{a}$ & $25 \pm 1.2 \mathrm{a}$ & $15 \pm 1.0 \mathrm{ab}$ \\
Hydropriming 24 h & $140 \pm 1.6 \mathrm{a}$ & $26 \pm 0.4 \mathrm{a}$ & $15 \pm 0.1 \mathrm{a}$ \\
Osmopriming12 $\mathrm{h}$ & $146 \pm 1.3 \mathrm{a}$ & $20 \pm 0.6 \mathrm{~b}$ & $12 \pm 0.2 \mathrm{bc}$ \\
Osmopriming 24 $\mathrm{h}$ & $146 \pm 0.6 \mathrm{a}$ & $20 \pm 0.4 \mathrm{~b}$ & $12 \pm 0.2 \mathrm{c}$ \\
Halopriming 12 $\mathrm{h}$ & $144 \mathrm{a} \pm 6.9$ & $21 \pm 1.9 \mathrm{ab}$ & $13 \pm 0.5 \mathrm{abc}$ \\
Halopriming 24 $\mathrm{h}$ & $144 \pm 5.3 \mathrm{a}$ & $21 \pm 1.2 \mathrm{ab}$ & $13 \pm 0.7 \mathrm{abc}$ \\
Hormopriming 12 h & $145 \pm 4.8 \mathrm{a}$ & $20 \pm 0.8 \mathrm{~b}$ & $12 \pm 0.5 \mathrm{bc}$ \\
Hormopriming 24 h & $144 \pm 1.7 \mathrm{a}$ & $20 \pm 1.4 \mathrm{~b}$ & $12 \pm 0.9 \mathrm{bc}$ \\
\hline
\end{tabular}

Within column, means followed by the same small letter are not different at the 0.05 level of probability using Tukey's HSD test.

Unfilled grains panicle ${ }^{-1}$ was $20 \%$ lower in osmopriming and hormopriming treatments compared to control and hydropriming treatments in 2018, whereas halopriming treatments did not differ from any of the priming treatments and the control (Tables 10 and 11). In 2019, unfilled grains panicle ${ }^{-1}$ was $>30 \%$ lower in osmopriming treatments, and $25 \%$ lower in halopriming and hormopriming treatments compared to control and hydropriming treatments. Unfilled grains panicle ${ }^{-1}$ was $23 \%$ lower in vattar/soil mulch DSR than in the conventional DSR method.

Sterility \% was the highest in control and hydropriming treatments (15\% in 2018, and $15-16 \%$ in 2019), whereas it was significantly lower in osmopriming (12\% in 2018 , and $10 \%$ in 2019) and hormopriming ( $12 \%$ in both years). Halopriming treatments did not differ in sterility \% from the control and hydropriming in 2018 but sterility was lower in halopriming treatments than in control and hydropriming in 2019. Like unfilled grain, sterility \% was $33 \%$ lower in vattar/soil mulch DSR than in the conventional DSR method. Grain, straw yield, and harvest index was not affected by the DSR establishment method (vattar/soil 
mulch DSR and conventional DSR) but during both years, priming treatments significantly affected rice yields (Tables 12 and 13). In both years, halopriming and hormopriming, irrespective of duration of priming (12 or $24 \mathrm{~h}$ ), produced higher rice yields than the control. In 2018, compared to the control (dry and non-primed seed), halopriming and hormopriming treatments resulted in 7-11\% higher yields and osmopriming treatments resulted in $4 \%$ higher yield. Like 2018, rice yields in 2019 were also $9-11 \%$ higher under halopriming and hormopriming treatments than the control. In contrast, rice yields under osmopriming treatments did not differ from that of the control. In both years, the yields of hydropriming treatments and the control did not differ. Overall, yields were higher in 2018 compared to 2019 (8.5 versus 7.4 tha $^{-1}$ ). The interaction effects of priming treatments and DSR establishment methods were non-significant (Table 13).

Table 11. Yield attributes (filled and unfilled grains per panicle and sterility \%) of rice as affected by different seed priming and DSR establishment methods during 2019 at Ludhiana, India.

\begin{tabular}{lccc}
\hline Treatment & $\begin{array}{c}\text { Number of Filled Grain } \\
\text { Per Panicle }\end{array}$ & $\begin{array}{c}\text { Number of Unfilled Grain } \\
\text { Per Panicle }\end{array}$ & Sterility (\%) \\
\hline & (A) Priming treatment & \\
Control (dry seed) & $131 \pm 5.4 \mathrm{~b}$ & $24 \pm 1.8 \mathrm{a}$ & $16 \pm 1.4 \mathrm{a}$ \\
Hydropriming 12 $\mathrm{h}$ & $130 \pm 5.2 \mathrm{~b}$ & $24 \pm 1.5 \mathrm{a}$ & $15 \pm 1.3 \mathrm{a}$ \\
Hydropriming 24 h & $130 \pm 5.3 \mathrm{~b}$ & $24 \pm 1.5 \mathrm{a}$ & $15 \pm 1.2 \mathrm{a}$ \\
Osmopriming12 $\mathrm{h}$ & $138 \pm 4.9 \mathrm{a}$ & $16 \pm 1.2 \mathrm{~b}$ & $10 \pm 1.0 \mathrm{~b}$ \\
Osmopriming 24 $\mathrm{h}$ & $138 \pm 4.6 \mathrm{a}$ & $15 \pm 1.3 \mathrm{~b}$ & $10 \pm 1.0 \mathrm{~b}$ \\
Halopriming 12 $\mathrm{h}$ & $135 \pm 4.8 \mathrm{a}$ & $18 \pm 1.0 \mathrm{~b}$ & $12 \pm 1.0 \mathrm{~b}$ \\
Halopriming 24 $\mathrm{h}$ & $136 \pm 5.6 \mathrm{a}$ & $18 \pm 1.4 \mathrm{~b}$ & $12 \pm 1.2 \mathrm{~b}$ \\
Hormopriming 12 h & $135 \pm 5.9 \mathrm{a}$ & $18 \pm 1.3 \mathrm{~b}$ & $12 \pm 1.2 \mathrm{~b}$ \\
Hormopriming 24 h & $136 \pm 5.2 \mathrm{a}$ & $18 \pm 1.3 \mathrm{~b}$ & $12 \pm 1.1 \mathrm{~b}$ \\
& (B) DSR method & $22 \pm 0.7 \mathrm{a}$ & $15 \pm 0.5 \mathrm{a}$ \\
Conventional DSR & $124 \pm 0.9 \mathrm{~b}$ & $17 \pm 0.7 \mathrm{~b}$ & $10 \pm 0.4 \mathrm{~b}$ \\
Soil mulch DSR & $146 \pm 1.0 \mathrm{a}$ & & \\
\hline & ANOVA ( $p$-value) & $<0.0001$ & $<0.0001$ \\
\hline Priming (P) & 0.0069 & $<0.0001$ & $\mathrm{NS}$ \\
DSR method (M) & $<0.0001$ & NS & \\
P $\times$ M interaction & NS & & \\
\hline
\end{tabular}

Within column for each factor, means followed by the same small letter are not different at the 0.05 level of probability using Tukey's HSD test.

Table 12. Grain yield, straw yield and harvest index of DSR as affected by different seed priming in conventional DSR establishment method during 2018 at Ludhiana, India.

\begin{tabular}{|c|c|c|c|}
\hline Treatment & Grain Yield (t ha ${ }^{-1}$ ) & Straw Yield ( $\mathrm{tha}^{-1}$ ) & Harvest Index (\%) \\
\hline Control (dry seed) & $8.1 \pm 0.04 \mathrm{~d}^{2}$ & $10.3 \pm 1.1 \mathrm{a}$ & $44 \pm 2.2 \mathrm{a}$ \\
\hline Hydropriming $12 \mathrm{~h}$ & $8.2 \pm 0.04 \mathrm{~cd}$ & $10.4 \pm 0.7 \mathrm{a}$ & $44 \pm 1.8 \mathrm{a}$ \\
\hline Hydropriming $24 \mathrm{~h}$ & $8.3 \pm 0.03 \mathrm{~cd}$ & $10.5 \pm 1.1 \mathrm{a}$ & $44 \pm 2.1 \mathrm{a}$ \\
\hline Osmopriming12 h & $8.4 \pm 0.03 b c$ & $10.6 \pm 0.3 \mathrm{a}$ & $44 \pm 0.7 \mathrm{a}$ \\
\hline Osmopriming $24 \mathrm{~h}$ & $8.4 \pm 0.12 b c$ & $10.5 \pm 0.3 \mathrm{a}$ & $45 \pm 0.4 \mathrm{a}$ \\
\hline Halopriming $12 \mathrm{~h}$ & $8.9 \pm 0.08 \mathrm{a}$ & $10.8 \pm 1.1 \mathrm{a}$ & $45 \pm 2.8 \mathrm{a}$ \\
\hline Halopriming $24 \mathrm{~h}$ & $9.0 \pm 0.04 \mathrm{a}$ & $10.9 \pm 1.0 \mathrm{a}$ & $45 \pm 2.5 \mathrm{a}$ \\
\hline Hormopriming $12 \mathrm{~h}$ & $8.7 \pm 0.1 \mathrm{ab}$ & $10.8 \pm 1.0 \mathrm{a}$ & $45 \pm 2.7 \mathrm{a}$ \\
\hline Hormopriming $24 \mathrm{~h}$ & $8.9 \pm 0.07 a$ & $10.9 \pm 0.9 \mathrm{a}$ & $45 \pm 1.8 \mathrm{a}$ \\
\hline
\end{tabular}

Within column, means followed by the same small letter are not different at the 0.05 level of probability using Tukey's HSD test. 
Table 13. Grain yield, straw yield and harvest index of DSR as affected by different seed priming and DSR establishment methods during 2019 at Ludhiana, India.

\begin{tabular}{|c|c|c|c|}
\hline Treatment & Grain Yield (t ha-1) & Straw Yield (t ha-1) & Harvest Index (\%) \\
\hline \multicolumn{4}{|c|}{ (A) Priming treatment } \\
\hline Control (dry seed) & $7.0 \pm 0.08 \mathrm{c}$ & $9.0 \pm 0.6 \mathrm{a}$ & $44 \pm 1.3 \mathrm{a}$ \\
\hline Hydropriming $12 \mathrm{~h}$ & $7.2 \pm 0.09 c$ & $9.1 \pm 0.4 \mathrm{a}$ & $44 \pm 1.2 \mathrm{a}$ \\
\hline Hydropriming $24 \mathrm{~h}$ & $7.2 \pm 0.06 c$ & $8.9 \pm 0.2 \mathrm{a}$ & $45 \pm 0.7 \mathrm{a}$ \\
\hline Osmopriming $12 \mathrm{~h}$ & $7.3 \pm 0.03 \mathrm{bc}$ & $9.1 \pm 0.1 \mathrm{a}$ & $45 \pm 0.3 \mathrm{a}$ \\
\hline Osmopriming $24 \mathrm{~h}$ & $7.3 \pm 0.05 b c$ & $9.1 \pm 0.1 \mathrm{a}$ & $45 \pm 0.5 \mathrm{a}$ \\
\hline Halopriming $12 \mathrm{~h}$ & $7.6 \pm 0.05 \mathrm{ab}$ & $9.3 \pm 0.2 \mathrm{a}$ & $45 \pm 0.6 \mathrm{a}$ \\
\hline Halopriming $24 \mathrm{~h}$ & $7.7 \pm 0.06 \mathrm{a}$ & $9.4 \pm 0.2 \mathrm{a}$ & $45 \pm 0.5 \mathrm{a}$ \\
\hline Hormopriming $12 \mathrm{~h}$ & $7.7 \pm 0.07 \mathrm{a}$ & $9.4 \pm 0.2 \mathrm{a}$ & $45 \pm 0.6 \mathrm{a}$ \\
\hline Hormopriming $24 \mathrm{~h}$ & $7.8 \pm 0.06 \mathrm{a}$ & $9.5 \pm 0.3 \mathrm{a}$ & $45 \pm 0.6 \mathrm{a}$ \\
\hline \multicolumn{4}{|c|}{ (B) DSR method } \\
\hline Conventional DSR & $7.5 \pm 0.05 \mathrm{a}$ & $9.4 \pm 0.1 \mathrm{a}$ & $44.4 \pm 0.3 \mathrm{a}$ \\
\hline Soil mulch DSR & $7.4 \pm 0.07 \mathrm{c}$ & $9.0 \pm 0.1 \mathrm{a}$ & $45.1 \pm 0.3 \mathrm{a}$ \\
\hline \multicolumn{4}{|c|}{ ANOVA ( $p$-value) } \\
\hline Priming $(\mathrm{P})$ & $<0.0001$ & NS & NS \\
\hline DSR method (M) & NS & NS & NS \\
\hline $\mathrm{P} \times \mathrm{M}$ interaction & NS & NS & NS \\
\hline
\end{tabular}

Within column for each factor, means followed by the same small letter are not different at the 0.05 level of probability using Tukey's HSD test.

\section{Discussion}

Seed priming is a pre-sowing treatment that modifies the seed's physiological and metabolic state and enables seed to germinate more efficiently and tolerate abiotic stresses better, leading to improved emergence, uniform and faster crop establishment, and higher early vigor [40]. Risks of poor and uneven crop establishment and higher weed infestations leading to lower yields are major bottlenecks in wide-scale adoption of DSR $[9,20]$. Therefore, seed priming techniques were evaluated to identify options that can reduce the risk of poor or uneven crop establishment, leading to improved performance of DSR. Although priming effect has been studied widely in different crops, limited studies have been conducted in DSR under Indian conditions where DSR is established using two methods-conventional DSR and vattar/soil mulch DSR. Moreover, the majority of the previous seed priming studies were conducted under laboratory conditions with a focus on seed germination/emergence attributes, and early growth and vigor, but very limited studies have evaluated priming impact at later stages of growth and on grain yield [48]. This study examined the impact of priming treatments, not only on germination/emergence and early growth parameters, but also on yield attributes and rice grain yield. Furthermore, to our knowledge, this is the first study which has assessed the effect of priming on vattar/soil mulch DSR.

\subsection{Laboratory Study}

Results from laboratory experiments showed that halopriming with $2 \% \mathrm{KNO}_{3}$ and hormopriming with $50 \mathrm{ppm}$ of $\mathrm{GA}_{3}$ improved seed germination, root and shoot length, and seedling vigor index 1 and 2, but seedling dry weight at 14 DAS was not affected compared to the control (non-primed dry seed) (Table 1). The reason for no effect of halopriming and hormopriming on seedling dry weight despite positive impact on root and shoot length could be that the experimental duration was too short (14 days) to reflect impact on dry weight; if the experiment was longer, the effects could have been reflected in dry weight. An increasing tendency in dry weight in these priming treatments can be noted (Table 1), although it was not statistically different within the 14 days of the experimental period. In this study, hydropriming did not affect any of these parameters, whereas osmopriming improved root and vigor index 1 but did not affect germination, shoot length, total dry weight, and vigor index 2 (Table 1). Similar to our results, another study from the same 
geography (Punjab, India) also reported no significant effect of hydropriming on time taken to $50 \%$ germination of rice [49], whereas in other research, hydropriming resulted in rapid germination of both coarse and fine-rice varieties [50]. The possible cause of no response of hydropriming in this study could be because the seed used in the study was of good quality with low dormancy and high germination percentage $(89 \%)$ even without any priming treatment. By comparison, the study that found higher germination rate and germination percentage reported that the improved germination in their study could be attributed to breakdown of dormancy by hydropriming because fresh seeds were used in the experiment [50]. In contrast to our results, other studies reported a positive impact of hydropriming on radical length and seedling vigor $[49,50]$. Similar to our study, many other researchers also observed the positive impact of halopriming with $\mathrm{KNO}_{3}$ and hormopriming with $\mathrm{GA}_{3}$ on seed germination, root and shoot length, and early vigor in rice [51-53]. In general, many other studies have reported positive effects of seed priming treatments on rice seed germination under normal and stress conditions $[37,41,46,53,54]$.

\subsection{Field Study}

Results of the field study suggest that halopriming with $2.0 \%$ potassium nitrate and hormopriming with $50 \mathrm{ppm} \mathrm{GA}$ have good potential to improve crop establishment (Tables 2 and 3), growth (Tables 4 and 5), and yields of rice (Tables 12 and 13) in DSR systems. The higher rice yields in halopriming and hydropriming were attributed to rapid emergence, higher establishment, better root and crop growth, and improvement in yield attributes compared to the non-primed control treatment (Tables 2-11). The faster, uniform, and higher seedling emergence and growth are crucial in DSR, and determine crop establishment, crop-weed competition, and yield [20,48,49]. It has been reported that rapidly germinating seedlings could emerge and produce a deep root system leading to uniform and good crop establishment for attaining potential yield levels [23]. Rapid, uniform, and good crop establishment with early vigor can also improve the competitiveness of rice against weeds leading to better yield, especially in DSR where weeds are one of the major constraints in attaining optimal DSR yields [9,55]. Many researchers have reported advantages of seed priming in terms of faster emergence, early vigor, crop establishment, crop growth, and yields in rice under weed stress [55], chilling stress [48], flooding stress [56] and normal/no stress conditions [37,40,41,49]. The improvement in germination or emergence, early vigor, and higher tolerance to stress conditions (drought, salinity, cold, etc.) was reported because of improved activities of $\alpha$-amylase, superoxide dismutase (SOD), catalase (CAT), and scavenger reactive oxygen species, resulting in carbohydrate mobilization and decrease in lipid peroxidation [37,42,55], and increase in cell division and expansion of embryonic axis $[40,57,58]$.

The increase in root length and shoot biomass due to hydropriming ( $24 \mathrm{~h}$ soaking) has been reported [59]. Similarly, others also reported a significant effect of hydropriming on growth and rice yield $[49,60]$. In our study, however, no significant enhancement in germination/emergence, growth, or yield was observed under hydropriming treatment. This may be because the hydropriming technique may result in an unequal degree of seed hydration, thus leading to lack of simultaneous metabolic activation within seeds followed by unsynchronized emergence, as reported by other researchers [61]. These results also highlight the important of evaluating priming treatments under different locations to generate more consensus and evidence.

Osmopriming with PEG in this study showed variable results with improvement in rice yield (4\%) in 2018 only (Table 12), whereas its effect was consistent in both years on improvement in root mass density (Tables 6 and 7), SPAD value (Tables 4 and 5), reduction in spikelet sterility, and unfilled grain panicle ${ }^{-1}$ (Tables 10 and 11), and showed no effect on crop emergence rate and final crop establishment (Tables 2 and 3). The higher SPAD value in osmopriming treatment could be attributed to higher root mass density, which might have improved the availability of resources including water and nutrients to crop plants through higher uptake compared to the control treatment (non-primed dry seed). The 
improvement in root growth, and uptake of water and nutrients leading to higher SPAD value, may have reduced the spikelet sterility. This enhancement in root mass density is likely attributed to the stress imprints imposed during seed osmopriming on reduced availability of water to seeds. Other researchers have also reported positive impact of osmopriming with PEG on better root growth [59,62], and on germination, emergence, and seedling establishment in several crops, including rice $[28,62-67]$ under stress conditions. Osmopriming improves stress tolerance by strengthening the antioxidant system (e.g., ascorbate peroxidase (APX), peroxidase (POD), CAT, and SOD) and osmotic regulation [27]. Our study was conducted under fully irrigated conditions which could be the reason that we did not observe an osmopriming effect on emergence and early growth (Tables 1-3). DSR can experience some mild moisture stress even under irrigated systems because the fields in DSR are not kept flooded, as is the case in transplanted rice. This could be one of the reasons for the positive impact of osmopriming on root growth and SPAD value.

Similar to our results, many other researchers also observed a positive impact of halopriming using $\mathrm{KCl}, \mathrm{CalCl}_{2}$, and $\mathrm{KNO}_{3}$, and of hormopriming using $\mathrm{GA}_{3}$ on germination and emergence attributes, early growth, and grain yield in rice and other crops under normal and stress (salinity, drought) conditions $[37,65,68,69]$.The higher emergence in hormopriming with $\mathrm{GA}_{3}$ could partially be because it stimulates elongation of mesocotyl and coleoptile, and thereby withstands adverse conditions, such as deeper seeding or flooding stress during emergence [52,54]. In this study, across all priming treatments, we did not find a significant effect of priming duration ( 12 or $24 \mathrm{~h}$ ). This may be ascribed to the fact that soaking of seed for $12 \mathrm{~h}$ in priming material might be sufficient to bring about the necessary changes in physiological processes responsible for the beneficial effect of priming.

\subsection{Conventional DSR versus Vattar/Soil Mulch DSR}

Irrespective of priming treatments, total emergence was lower in vattar/soil mulch DSR than conventional DSR. Additionally, rate of emergence, time to start and completion of emergence (Table 3), and days taken to $50 \%$ flowering (Table 5) were slower/delayed in vattar DSR compared to conventional DSR. This could be due to lower moisture in vattar DSR than conventional DSR at the early crop establishment phase because the first irrigation was withheld for 21 days in vattar/soil mulch DSR. The lower tiller density (Table 5 in vattar DSR compared to conventional DSR could be due to the overall lower plant population (71 versus $85 \mathrm{~m}^{-2}$; Table 2). In contrast, SPAD value in vattar/soil mulch DSR was higher than that in conventional DSR (Table 5). This could be attributed to higher root mass density (Table 7), which may be due to low soil moisture in vattar/soil mulch DSR in the first 20 days compared to conventional DSR, leading to more root development and higher uptake of nutrients and water. Despite lower tiller density in vattar/soil mulch DSR than conventional DSR, grain yield of vattar/soil mulch DSR did not differ from that of conventional-DSR. This was because lower tiller density was compensated for by higher filled grain panicle ${ }^{-1}$, lower unfilled grain panicle ${ }^{-1}$, lower spikelet sterility, and higher panicle weight compared to conventional DSR. These results suggest that both conventional DSR and vattar DSR are equally productive but vattar/soil mulch DSR offers more potential to save irrigation water by reducing early irrigation requirements for the first 20 days by conserving soil moisture [16,17]. It has also been reported that vattar/soil mulch DSR reduces early weed pressure by $40-60 \%$ compared to conventional DSR [16]. Therefore, vattar/soil mulch DSR should be promoted over conventional DSR to conserve irrigation water and to minimize risk of weed infestation in DSR.

\section{Conclusions}

Our results demonstrated that halopriming with $2 \% \mathrm{KNO}_{3}$ and hormopriming with 50 ppm $\mathrm{GA}_{3}$ can improve the performance of DSR by improving crop establishment (faster and higher crop emergence), seedling vigor, root density biomass, yield attributes, and grain yield compared to DSR without seed priming. These results also indicate that 
halopriming and hormopriming can help overcome the problem of poor and uneven crop establishment in DSR systems, thereby helping attain optimal yield of both conventional DSR and vattar/soil mulch DSR. Osmopriming with PEG increased root mass density and crop growth (higher SPAD value), and reduced spikelet sterility and unfilled grains, but its impact on yield was inconsistent, with a positive impact in 2018 but no effect in 2019.These findings indicate that halopriming and hormopriming — an easy and affordable technique-should be promoted to make DSR more successful. Further research to quantify the positive impact of priming techniques, especially in farmers' fields under varying conditions (favorable and stress), would help scaling these seed invigoration techniques in DSR-based systems in India.

Supplementary Materials: The supplementary materials are available online at https:/ /www.mdpi. com/article/10.3390/agronomy11050849/s1, Supplementary Figure S1: Experimental layout in 2018 (A) and 2019 (B); Supplementary Table S1: Summary of crop management and field operations in field study during 2018 and 2019,

Author Contributions: Conceptualization, B.S.D., V.K. and G.S.M.; methodology, B.S.D., V.K., N.K. and P.S.; analysis, B.S.D. and V.K.; investigation, B.S.D. and N.K.; writing—original draft preparation, B.S.D., P.S., and N.K.; writing—review and editing, V.K., G.S.M. and S.S.; funding acquisition, V.K. and S.S. All authors have read and agreed to the published version of the manuscript.

Funding: This research was funded by International Rice Research Institute, Los Baños, Philippines under Direct seeded Rice consortium.

Institutional Review Board Statement: Not applicable.

Informed Consent Statement: Not applicable.

Data Availability Statement: The data presented in this study are available on request from the corresponding author. The data are not publicly available due to privacy.

Acknowledgments: Authors acknowledge the support of Punjab Agricultural University, Ludhiana for providing necessary facilities for carrying out the research work and International Rice Research Institute (IRRI) for financial support through its Direct Seeded Rice Consortium (DSRC).

Conflicts of Interest: The authors declare no conflict of interest.

\section{Abbreviations}

h hour

DSR direct-seeded rice

Conv-DSR conventional dry direct-seeded rice

\section{References}

1. Khir, R.; Pan, Z. Rice. In Integrated Processing Technologies for Food and Agricultural By-Products; Pan, Z., Zhang, R., Zicari, S., Eds.; Academic Press: Orlando, FL, USA, 2019; Volume 2, pp. 21-58. ISBN 9780128141380.

2. FAO. FAOSTAT Database; Food and Agriculture Organization of the United Nations (FAO): Rome, Italy, 2018; Available online: http:/ / www.fao.org/faostat/en/ (accessed on 7 January 2021).

3. APEDA. Analytical Report of APEDA Products. Available online: http:/ /agriexchange.apeda.gov.in (accessed on 1 April 2021).

4. Kumar, V.; Jat, H.S.; Sharma, P.C.; Gathala, M.K.; Malik, R.K.; Kamboj, B.R.; Yadav, A.K.; Ladha, J.K.; Raman, A.; Sharma, D.K. Can productivity and profitability be enhanced in intensively managed cereal systems while reducing the environmental footprint of production? Assessing sustainable intensification options in the breadbasket of India. Agric. Ecosyst. Environ. 2018, 252, 132-147. [CrossRef]

5. Chakraborty, D.; Ladha, J.K.; Rana, D.S.; Jat, M.L.; Gathala, M.K.; Yadav, S.; Rao, A.N.; Ramesha, M.S.; Raman, A. A global analysis of alternative tillage and crop establishment practices for economically and environmentally efficient rice production. Sci. Rep. 2017, 7, 1-11. [CrossRef]

6. Dhillon, B.S.; Mangat, G.S. Direct seeded rice in Punjab: Opportunities and challenges. In Proceedings of the National Seminar on Sustainable Rice Production Technology for Increasing the Farmers' Income, Raipur, India, 20-21 January 2018.

7. Chauhan, B.S.; Awan, T.H.; Abugho, S.B.; Evengelista, G.; Yadav, S. Effect of crop establishment methods and weed control treatments on weed management, and rice yield. Field Crop. Res. 2015, 172, 72-84. [CrossRef] 
8. Fageria, N.K.; Carvalho, G.D.; Santos, A.B.; Ferreira, E.P.B.; Knupp, A.M. Chemistry of lowland rice soils and nutrient availability. Commun. Soil Sci. Plant Anal. 2011, 42, 1913-1933. [CrossRef]

9. Kumar, V.; Ladha, J.K. Direct seeding of rice: Recent developments and future research needs. Adv. Agron. 2011, 111, $297-413$.

10. Kumar, S. Weed management practices in direct seeded rice (Oryza sativa L.): A review. J. Pharmacogn. Phytochem. 2018, 7, 2356-2362.

11. Kalita, J.; Ahmed, P.; Baruah, N. Puddling and its effect on soil physical properties and growth of rice and post rice crops: A review. J. Pharmacogn. Phytochem. 2020, 9, 503-510.

12. Devkota, K.P.; Yadav, S.-; Khanda, C.; Beebout, S.J.; Mohapatra, B.K.; Singleton, G.R.; Puskur, R. Assessing alternative crop establishment methods with a sustainability lens in rice production systems of Eastern India. J. Clean. Prod. 2020, $244,118835$. [CrossRef]

13. Basavalingaiah, K.; Ramesha, Y.; Paramesh, V.; Rajanna, G.; Jat, S.L.; Misra, S.D.; Gaddi, A.K.; Girisha, H.; Yogesh, G.; Raveesha, S.; et al. Energy budgeting, data envelopment analysis and greenhouse gas emission from rice production system: A case study from puddled transplanted rice and direct-seeded rice system of Karnataka, India. Sustainability 2020, 12, 6439. [CrossRef]

14. Hellin, J.; Balie, J.; Fisher, E.; Kohli, A.; Connor, M.; Yadav, S.; Kumar, V.; Krupnik, T.J.; Sander, B.O.; Cobb, J.; et al. Transdisciplinary responses to climate change: Lessons from rice-based systems in Asia. Climate 2020, 8, 35. [CrossRef]

15. Aryal, J.; Jat, M.L.; Sapkota, T.; Rahut, D.B.; Rai, M.; Jat, H.S.; Sharma, P.C.; Stirling, C. Learning adaptation to climate change from past climate extremes: Evidence from recent climate extremes in Haryana, India. Int. J. Clim. Chang. Strateg. Manag. 2019, 12, 128-146. [CrossRef]

16. CSISA. Annual Report 2016-Cereal Systems Initiative for South Asia. 2016. Available online: www.csisa.org (accessed on 25 November 2020).

17. Bhatti, D.S.; Kaur, S. Package of Practices for Kharif Crops in Punjab; Punjab Agricultural University Ludhiana; Foilprinters Press: Ludhiana, India, 2019; pp. 1-20.

18. Ranbir, S.; Tripathi, R.S.; Sharma, D.K.; Chaudhari, S.K.; Joshi, P.K.; Dey, P.; Sharma, S.K.; Sharma, D.P.; Gurbachan, S. Effect of direct seeded rice on yield, water productivity and saving of farm energy in reclaimed sodic soil. Indian J. Soil Conserv. 2019, 43, 230-235.

19. Bhullar, M.S.; Singh, S.; Kumar, S.; Gill, G. Agronomic and economic impacts of direct seeded rice in Punjab. Agric. Res. J. 2018, 55, 236-242. [CrossRef]

20. Xu, L.; Li, X.; Wang, X.; Xiong, D.; Wang, F. Comparing the grain yields of direct-seeded and transplanted rice: A meta-analysis. Agronomy 2019, 9, 767. [CrossRef]

21. Saha, S.; Munda, S.; Singh, S.; Kumar, V.; Jangde, H.; Mahapatra, A.; Chauhan, B. Crop establishment and weed control options for sustaining dry direct seeded rice production in Eastern India. Agronomy 2021, 11, 389. [CrossRef]

22. Sandhu, N.; Torres, R.; Sta Cruz, M.T.; Maturan, P.C.; Jain, R.; Kumar, A.; Henry, A. Traits and QTLs for development of dry direct seeded rainfed rice varieties. J. Exp. Bot. 2015, 66, 225-244. [CrossRef]

23. Sandhu, N.; Yadaw, R.B.; Chaudhary, B.; Prasai, H.; Iftekharuddaula, K.; Venkateshwarlu, C.; Annamalai, A.; Xangsayasane, P.; Battan, K.R.; Ram, M.; et al. Evaluating the performance of rice genotypes for improving yield and adaptability under direct seeded aerobic cultivation conditions. Front. Plant Sci. 2019, 10, 159. [CrossRef]

24. Alam, K.; Bell, R.W.; Hasanuzzaman, M.; Salahin, N.; Rashid, M.; Akter, N.; Akhter, S.; Islam, M.S.; Islam, S.; Naznin, S.; et al. Rice (Oryza sativa L.) establishment techniques and their implications for soil properties, global warming potential mitigation and crop yields. Agronomy 2020, 10, 888. [CrossRef]

25. CSISA. Annual Report 2017-Cereal Systems Initiative for South Asia. 2017. Available online: www.csisa.org (accessed on 7 January 2021).

26. CSISA. Annual Report 2018-Cereal Systems Initiative for South Asia. 2018. Available online: www.csisa.org (accessed on 7 January 2021).

27. Marthandan, V.; Geetha, R.; Kumutha, K.; Renganathan, V.G.; Karthikeyan, A.; Ramalingam, J. Seed Priming: A feasible strategy to enhance drought tolerance in crop plants. Int. J. Mol. Sci. 2020, 21, 8258. [CrossRef] [PubMed]

28. Rashid, A.; Harris, D.; Hollington, P.; Ali, S. On-farm seed priming reduces yield losses of mungbean (Vigna radiata) associated with mungbean yellow mosaic virus in the North West Frontier Province of Pakistan. Crop Prot. 2014, 23, 1119-1124. [CrossRef]

29. Lewandowska, S.; Łoziński, M.; Marczewski, K.; Kozak, M.; Schmidtke, K. Influence of priming on germination, development, and yield of soybean varieties. Open Agric. 2020, 5, 930-935. [CrossRef]

30. Zhang, F.; Yu, J.; Johnston, C.R.; Wang, Y.; Zhu, K.; Lu, F.; Zhang, Z.; Zou, J. Seed priming with polyethylene glycol induces phys-iological changes in sorghum (Sorghum bicolor L. Moench) seedlings under suboptimal soil moisture environments. PLoS ONE 2015, 10, e0140620. [CrossRef]

31. Nawaz, A.; Farooq, M.; Ahmad, R.; Basra, S.M.A.; Lal, R. Seed priming improves stand establishment and productivity of no till wheat grown after direct seeded aerobic and transplanted flooded rice. Eur. J. Agron. 2016, 76, 130-137. [CrossRef]

32. Tabassum, T.; Farooq, M.; Ahmad, R.; Zohaib, A.; Wahid, A.; Shahid, M. Terminal drought and seed priming improves drought tolerance in wheat. Physiol. Mol. Biol. Plants 2018, 24, 845-856. [CrossRef] [PubMed]

33. Canak, P.; Mirosavljevic, M.; Mitrovic, B.; Ciric, M.; Keselj, J.; Vujosevic, B.; Stanisavljevic, D. Effect of seed priming on seed vigor and early seedling growth in maize under optimal and suboptimal temperature conditions. Sel. Semen. 2016, 22, 17-25. [CrossRef] 
34. Rasool, T.; Ahmad, R.; Farooq, M. Seed priming with micronutrients for improving the quality and yield of hybrid maize. Gesunde Pflanz. 2018, 71, 37-44. [CrossRef]

35. Ali, M.M.; Javed, T.; Mauro, R.; Shabbir, R.; Afzal, I.; Yousef, A. Effect of seed priming with potassium nitrate on the performance of tomato. Agriculture 2020, 10, 498. [CrossRef]

36. Farooq, M.; Basra, S.M.A.; Tabassum, R.; Afzal, I. Enhancing the performance of direct seeded fine rice by seed priming. Plant Prod. Sci. 2006, 9, 446-456. [CrossRef]

37. Zheng, M.; Tao, Y.; Hussain, S.; Jiang, Q.; Peng, S.; Huang, J.; Cui, K.; Nie, L. Seed priming in dry direct-seeded rice: Consequences for emergence, seedling growth and associated metabolic events under drought stress. Plant Growth Regul. 2016, 78, 167-178. [CrossRef]

38. Farooq, M.; Usman, M.; Nadeem, F.; Rehman, H.U.; Wahid, A.; Basra, S.M.A.; Siddique, K.H.M. Seed priming in field crops: Potential benefits, adoption and challenges. Crop. Pasture Sci. 2019, 70, 731-771. [CrossRef]

39. Lutts, S.; Benincasa, P.; Wojtyla, L.; Kubala, S.; Pace, R.; Lechowska, K.; Quinet, M.; Garnczarska, M. Seed priming: New comprehensive approaches for an old empirical technique. In New Challenges in Seed Biology_Basic and Translational Research Driving Seed Technology; Araujo, S., Balestrazzi, A., Eds.; InTech: Daimlerstrase, Germany, 2016; ISBN 978-953-51-2658-4.

40. Du, B.; Luo, H.; He, L.; Zhang, L.; Liu, Y.; Mo, Z.; Pan, S.; Tian, H.; Duan, M.; Tang, X. Rice seed priming with sodium selenate: Effects on germination, seedling growth, and biochemical attributes. Sci. Rep. 2019, 9, 1-9. [CrossRef]

41. Ali, L.G.; Nulit, R.; Ibrahim, M.H.; Yien, C.Y.S. Enhancement of germination and early seedling growth of rice (Oryza sativa) var. FARO44 by seed priming under normal and drought stressed conditions. J. Plant Nutr. 2020, 43, 1579-1593. [CrossRef]

42. Arif, T.-U.; Afrin, S.; Polash, M.A.S.; Akter, T.; Ray, S.R.; Hossain, T.; Hossain, M.A. Role of exogenous signaling molecules in alleviating salt-induced oxidative stress in rice (Oryza sativa L.): A comparative study. Acta Physiol. Plant. 2019, 41, 69. [CrossRef]

43. Prabhjyot-Kaur; Sandhu, S.S.; Singh, H.; Kaur, N.; Singh, S.; Kaur, A. Climatic Features and Their Variability in Punjab; AICRPAM: Ludhiana, India, 2016; 78p.

44. ISTA. International Rules for Seed Testing; International Seed Testing Association (ISTA): Bassersdorf, Switzerland, $2015 ;$ pp. 1-276.

45. Michaelis, L.; Menten, M. Die kinetik der intervintwirkung. Biochem. Z. 1913, 49, 333-369.

46. Abdul-Baki, A.A.; Anderson, J.D. Vigor determination in soybean seed by multiple criteria 1. Crop. Sci. 1973, 13, 630-633. [CrossRef]

47. Yuan, Z.; Cao, Q.; Zhang, K.; Ata-Ul-Karim, S.T.; Tian, Y.; Zhu, Y.; Cao, W.; Liu, X. Optimal leaf positions for SPAD meter measurement in rice. Front. Plant Sci. 2016, 7, 719. [CrossRef] [PubMed]

48. Nie, L.; Liu, H.; Zhang, L.; Wang, W. Enhancement in rice seed germination via improved respiratory metabolism under chilling stress. Food Energy Secur. 2020, 9, 234. [CrossRef]

49. Mahajan, G.; Sarlach, R.S.; Japinder, S.; Gill, M.S. Seed priming effects on germination, growth and yield of dry direct-seeded rice. J. Crop Improv. 2011, 25, 409-417. [CrossRef]

50. Farooq, M.; Basra, S.; Afzal, I.; Khaliq, A. Optimization of hydropriming techniques for rice seed invigoration. Seed Sci. Technol. 2006, 34, 507-512. [CrossRef]

51. Basra, S.M.A.; Farooq, M.; Hafeez, K.; Ahmad, N. Osmohardening a new technique for rice seed invigoration. Int. Rice Res. Notes 2004, 29, 80-81.

52. Dunand, R.T. Gibberellic Acid Seed Treatment in Rice. LSU Agricultural Experiment Station Reports. 1993. Available online: http:/ / digitalcommons.lsu.edu/agexp/510 (accessed on 25 November 2020).

53. Ali, L.G.; Nulit, R.; Ibrahim, M.H.; Yien, C.Y.S. Efficacy of $\mathrm{KNO}_{3}, \mathrm{SiO}_{2}$ and SA priming for improving emergence, seedling growth and antioxidant enzymes of rice (Oryza sativa), under drought. Sci. Rep. 2021, 11, 1-11. [CrossRef] [PubMed]

54. Sukifto, R.; Nulit, R.; Kong, Y.C.; Sidek, N.; Mahadi, S.N.; Mustafa, N.; Razak, R.A. Enhancing germination and early seedling growth of Malaysian indica rice (Oryza sativa L.) using hormonal priming with gibberellic acid (GA3). AIMS Agric. Food 2020, 5, 649-665. [CrossRef]

55. Anwar, P.; Juraimi, A.S.; Puteh, A.; Selamat, A.; Rahman, M.; Samedani, B. Seed priming influences weed competitiveness and productivity of aerobic rice. Acta Agric. Scand. Sect. B Plant Soil Sci. 2012, 62, 1-11. [CrossRef]

56. Ella, E.S.; Dionisio-Sese, M.L.; Ismail, A.M. Seed priming improves crop establishment of rice in flooded soil. Crop Manag. Physiol. 2011, 36, 1-5.

57. Simon, E.W. Early events in germination. In Seed Physiology: Germination and Reserve Mobilization; Murray, D.R., Ed.; Academic Press: Orlando, FL, USA, 1984; Volume 2, pp. 77-115. ISBN 978-0125119023.

58. Basra, S.; Farooq, M.; Tabassam, R.; Ahmad, N. Physiological and biochemical aspects of pre-sowing seed treatments in fine rice (Oryza sativa L.). Seed Sci. Technol. 2005, 33, 623-628. [CrossRef]

59. Pame, A.R.; Kreye, C.; Johnson, D.; Heuer, S.; Becker, M. Effects of genotype, seed p concentration and seed priming on seedling vigor of rice. Exp. Agric. 2015, 51, 370-381. [CrossRef]

60. Goswami, A.; Banerjee, R.; Raha, S. Drought resistance in rice seedlings conferred by seed priming. Protoplasma 2013, 250, 1115-1129. [CrossRef] [PubMed]

61. Mcdonald, M.B. Seed priming. In Seed Technology and Its Biological Basis; Black, M., Bewley, J.D., Eds.; Sheffield Academic Press: Sheffield, UK, 2000; pp. 287-325.

62. Yuan-Yuan, S.U.; Yong-Jian, S.U.; Ming-Tian, W.A.; Xu-Yi, L.I.; Xiang, G.U.; Rong, H.U.; Jun, M.A. Effects of seed priming on germination and seedling growth of rice under water stress. Acta Agron. Sin. 2010, 36, 1931-1940. 
63. Chen, K.; Arora, R. Dynamics of the antioxidant system during seed osmopriming, post-priming germination, and seedling establishment in Spinach (Spinacia oleracea). Plant Sci. 2011, 180, 212-220. [CrossRef] [PubMed]

64. Basra, S.M.A.; Farooq, M.; Hussain, M. Influence of osmopriming on the germination and early seedling growth of coarse and fine rice. Pak. J. Seed Technol. 2005, 6, 33-42.

65. Ruan, S.; Xue, Q.; Tylkowska, K. Effects of seed priming on emergence and health of rice (Oryza sativa L.) seeds. Seed Sci. Technol. 2002, 30, 451-458.

66. Hur, S. Effect of osmoconditioning on the productivity of Italian ryegrass and sorghum under suboptimal conditions. Korean J. Anim. Sci. 1991, 33, 101-105.

67. Jisha, K.C.; Puthur, J.T. Seed halopriming outdo hydropriming in enhancing seedling vigor and osmotic stress tolerance potential of rice varieties. J. Crop Sci. Biotechnol. 2014, 17, 209-219. [CrossRef]

68. Watanabe, K.; Oda-Yamamizo, C.; Sage-Ono, K.; Ohmiya, A.; Ono, M. Alteration of flower colour in Ipomoea nil through CRISPR/Cas9-mediated mutagenesis of carotenoid cleavage dioxygenase 4. Transgen. Res. 2018, 27, 25-38. [CrossRef]

69. Iqbal, M.; Ashraf, M. Gibberellic acid mediated induction of salt tolerance in wheat plants: Growth, ionic partitioning, photosynthesis, yield and hormonal homeostasis. Environ. Exp. Bot. 2013, 86, 76-85. [CrossRef] 